\title{
THE RULE OF REASON AND THE PER SE CONCEPT: PRICE FIXING AND MARKET DIVISION*
}

\author{
ROBERT H. BORK $\dagger$
}

I

THE purpose of this article is to develop, primarily in the context of pricefixing and market-division agreements, a general theory of the appropriate roles and criteria of the rule of reason and the per se concept in the decision of antitrust cases concerning the elimination of competition between agreeing parties.

The topics of antitrust are probably best classified - and the closeness of the relationships of phenomena to one another most accurately measured according to the methods by which particular practices are thought to injure competition. This results in two major categories, for the theory underlying current antitrust law supposes that there are two fundamentally distinct means by which competition may be lessened:

(1) Agreements by which consenting parties remove some or all of the competition existing or likely to exist between themselves; and

(2) Practices by which one or more parties injure competitors, and thereby injure the competitive process itself.

Agreements in the first group injure consumers directly by enabling the parties to restrict output, thus creating misallocation of resources. The theory concerning practices in the second category appears to be that by the exclusion of rivals parties may gain a market position which will make it profitable for them to restrict output. ${ }^{1}$

Price fixing and market division, the primary subjects of this paper, thus belong to a more general field which includes such related phenomena as agreements not to compete, concerted refusals to deal not intended to injure rivals, and horizontal mergers. The second category consists of such practices as

\footnotetext{
*This is the first section of an article to be published in two parts. The second part will appear in a forthcoming issue of The Yale Law Journal.

†Associate Professor of Law, Yale University.

1. The idea of injury to competition occurring through injury to competitors is discussed in Director \& Levi, Low ard the Future: Trade Regulation, 51 Nw. U.L. REv. 281 (1956); and in Bork \& Bowman, The Crisis In Antitrist, 65 Coluar. L. Rev. 363 (1965).

The main lines of the theory of injury to competition by agreements eliminating competition are well established. For a good statement of cartel theory, see AfcGee, Ocean Freight Rate Conferences and the American Merchant Marine, 27 U. CHI. L. Rev. 191, 196-204 (1960).
} 
price discrimination, concerted refusals to deal intended to injure competitors, exclusive dealing and requirements contracts, tying arrangements, vertical and conglomerate mergers, and growth to large size through efficiency. ${ }^{2}$ It is, in a sense, somewhat artificial to separate these classes of practices since they are very often present in the same factual setting and it is impossible to discuss the legality of many business arrangements without considering both. These two basic methods of injuring competition are, nevertheless, so clissimilar analytically that it is desirable to view them separately whenever basic theory is under discussion.

Price-fixing and market-division agreements have been among the primary concerns of the Sherman Act $^{3}$ ever since its passage. The courts are ustually represented as having wavered for a time and then settled upon firm rules of illegality for such agreements. Price fixing and market division are, in fact, frequently referred to as "hard core" or per se offenses whose legal statts, as contrasted with that of other practices and agreements cognizable by the antitrust laws, is so certain and well known as to justify the use of criminal process and sanctions. Yet it is becoming increasingly obvious that even in this central area the rules are far from clear. The courts have not succeeded in elaborating doctrine which is at once rooted in sound social policy, internally consistent, and able to cope comfortably with the problems for which the law is expected to supply solutions. Instead, current doctrine shows signs of strain and uneasiness which suggest that re-examination of fundamentals is due.

Though they occur in a great variety of business contexts and serve a number of purposes, price fixing and market division are merely special forms of the general phenomenon of elimination of competition. They are frequently explicit, but on economic grounds there seems no reason to distingtish between explicit and implicit eliminations of competition. The problem, then, is to state general rules by which it may be determined whether particular eliminations of competition are lawful or unlawful. The theoretical apparatus of the Sherman Act which is supposed to make such distinctions is generally known as the "rule of reason." Many commentators appear to believe that the rule of reason as it applies to loose arrangements eliminating competition has become

2. This classification is necessarily rough because the law's conventional descriptive groupings do not match the operative concepts of injury to competition. A liorizontal merger, for example, may sometimes be questioned under amended section 7 of the Clayton Act not because it eliminates competition between the merging parties but because together they may be more efficient (obtain a "competitive advantage") and thus injure rivals. The merger, as to that aspect at least, falls within the second category of antitrust rather than the first. Conversely, a "conglomerate" merger may be brought within the first category when the theory of injury to competition is that the merging parties were potential competitors. These possibilities of confusion can only be guarded against and not eliminated, for the operative concepts of the methods of injuring competition are too necessary to analysis, anit the conventional descriptive concepts probably too thoroughly established, to be discarded.

3. 26 Stat. 209 , 15 U.S.C. $§ \$ 1-7(1890)$. 
little more than a set of rules of per se illegality. Yet this is demonstrably not the case. The current shibboleth of per se illegality in existing law conveys a sense of certainty, even of automaticity, which is delusive. The per se concept does not accurately describe the law relating to agreements eliminating competition as it is, as it has been, or as it ever can be. Alongside cases announcing a sweeping per se formulation of the law there has always existed a line of cases refusing to apply it. Doubtless some of the cases in the latter group were wrongly decided, but it would be naive to write them all off as simply incorrect or aberrational. The persistent refusal of courts to honor the literal terms of the per se rules against price-fixing and market-division agreements demonstrates a deep-seated though somewhat inarticulate sense that those rules, as usually stated, are inadequate.

Antitrust's failure to be clear about the scope and office of the per se concept and about the criteria to be used outside the per se area arises from two distinct deficiencies: (1) A failure to analyze and select the goals or values the law may properly serve; and (2) a failure adequately to appreciate the nature of the economic phenomena with which the law must deal. The interaction of these two factors has caused the law to follow an apparently zigzag course of development. There. has been on the one hand, a strong line of cases apparently holding horizontal and vertical price fixing and horizontal market divisions per se illegal: Trans-Missouri (1897), Joint Traffic (1898), Addyston Pipe \& Stcel (1898), Dr. Miles (1911), Standard Oil (1911), American Tobacco (1911), Trenton Potteries (1927), Socony-Vacuun (1940), Kiefer-Stewart (1951), Timken Roller Bearing (1951), and Parke, Davis (1960). But there has simultaneously existed a line of cases opposing or limiting the per se idea: Chicago Board of Trade (1918), Standard Oil (Indiana) (1931), Appalachian Coals (1933), Bansch \& Lomb (1944), National Football League (1953), Denison Mattress (1962), and the recent line of Tobacco Warehouse Cases. These cases are merely leading examples of divergent lines of authority which the courts have never satisfactorily reconciled.

A striking display of the law's continuing theoretical discontinuities is provided by the Supreme Court's recent decisions in White Motor Co. and PennOlin Chemical Co. ${ }^{6}$ At issue in the White Motor case were the conditions imposed by White, a truck manufacturer, in its distributor and dealer contracts, that each reseller deal only with customers located within a designated territory and that certain customers, reserved for direct sales by White, not be dealt with at all. The case thus involved territorial limitations and customer allocations, both sub-species of market division. The government won its case

4. Professor Handler expresses what appears to be the prevailing impression: "The authorities upholding loose-knit arrangements are extremely sparse, deal mainly with sui generis states of fact, and have little precedential force." Hasdoler, Asitrtrost In PenSPECTIVE 26 (1957).

5. White Mrotor Co. v. United States, 372 U.S. 253 (1963).

6. United States v. Penn-Olin Chem. Co., 378 U.S. 158 (1964). 
on summary judgment in the district court, but the Supreme Court reversed and remanded for trial, splitting five to three on the question of whether the contract provisions were violative per se of the Sherman Act. Justice Douglas, usually thought of as an advocate of the per se approach, wrote the opinion of the Court stating that the case must go to trial since the Court did not know enough about the economic significance of White's arrangements to impose a per se rule at this stage. Justice Brennan concurred separately, offering suggestions as to the criteria which might guide the trial. Justice Clark wrote for the dissenters: "To admit, as does the petitioner, that competition is eliminated under its contracts is, under our cases, to admit a violation of the Sherman Act. No justification, no matter how beneficial, can save it from that interdiction." Within itself, then, the White Motor opinion reveals a surprising degree of disagreement on the Supreme Court concerning the very fundamental question of whether agreements eliminating competition are justifiable under any circumstances.

Perhaps equally surprisingly, the majority opinion, though it remanded the case for full trial, failed to state the criteria by which the category of agreements illegal per se were to be distinguished from those susceptible of justification. The opinion, as will be shown, is somewhat ambiguous: it is capable of being read as premised on economic theory or as suggesting that other than strictly economic considerations would ultimately play a part in the decision whether to fashion a per se rule. The dissent's insistence that every agreement eliminating competition is illegal seems based entirely on economic considerations. Thus the sharp differences displayed within the case may arise either from conflicting economic analyses or from disagreement concerning ultimate values.

The majority opinion's discontinuity with contiguous doctrinal structure is equally dramatic. White Motor involved vertically imposed divisions of markets. The Dr. Miles opinion of 1911 had decided that vertical fixing by a manufacturer of its dealers' prices was no more lawful than horizontal price fixing among the dealers would be. The law has never wavered from this position and resale price maintenance continues to be a per se offense. Given, also, the law's equation of price fixing and market division, ${ }^{8}$ it had, prior to White Motor, seemed inescapable that vertical market division would be

7. 372 U.S. at 281 (1963).

8. Price fixing and market division were treated as equally illegal in United States v. Addyston Pipe \& Steel Co., 85 Fed. 271 (6th Cir. 1898), aff'd, 175 U.S. 211 (1899). Since then in such cases as United States v. National Lead Co., 332 U.S. 319 (1947) (international division of territories), and United States v. Socony-Vacuum Oil Co., 310 U.S. 150 (1940) (price fixing), they have been generally treated the same. The equation scems justified since both price fixing and market division eliminate competition, the former of one of the most important terms of sale, the latter on all terms. Whitc Motor secms to indicate, however, that vertical price fixing will be viewed more severely by the law than vertical market division, and perhaps the same sort of distinction between horizontal price fixing and horizontal market division may be perceived recently in such opinions as Denison Mattress Factory v. Spring-Air Co., 308 F.2d 403 (5th Cir. 1962). 
placed in the class of per se violations alongside vertical price fixing. Perhaps the Court's refusal to take that step presages a willingness to re-examine its approach to both vertical and horizontal price fixing and horizontal market division. If not, probably White Motor will ultimately be discarded, for the doctrinal fissure it creates seems too glaring to endure long.

But, if White Motor disclosed disagreement on the Court and discontinuity with seemingly entrenched principles, a third and perhaps even more surprising development was provided by the subsequent Pcun-Olin decision, for there Justices Douglas and Clark exchanged positions on the very principle seemingly at stake in White Motor. Penn-Olin arose on the government's challenge, under both amended section 7 of the Clayton Act and section 1 of the Sherman Act, of the formation and equal ownership of a joint venture corporation, Penn-Olin Chemical Co., by Pennsalt Chemicals Corp. and Olin Mathieson Chemical Corp. Penn-Olin was set up to produce and sell sodium chlorate in the southeastern United States. Pennsalt was already a producer of sodium chlorate and Olin, a large consumer, had considered entering into production. The entrance of these very likely competitors into a joint venture agreement thus had the effect of eliminating much and perhaps all possibility of competition between them in the manufacture and sale of sodium chlorate in the Southeast. Justice Clark explicitly recognized this effect, ${ }^{9}$ and yet, writing for the majority, and without even mentioning his position in White Motor, held that the record revealed no violation of section 1 of the Sherman Act and remanded the case for further investigation of questions he thought presented by section 7 of the Clayton Act. Justice Clark offered no explanation for his apparent abandonment of his White Motor argument. It is true that the agreement eliminating competition was explicit in that case and merely inherent in the joining of the parties in Penn-Olin, but it seems impossible to believe that Justice Clark rested on a distinction shown to be inconsequential by his own reasoning. ${ }^{10}$

Justice Douglas, on the other hand, dissented, essentially on the ground that "Agreements among competitors to divide markets are per se violations of the Sherman Act."11 Using Sherman Act precedent and reasoning to find

9. Certainly the formation of a joint venture and purchase by the organizers of its stock would substantially lessen competition - indeed foreclose it - as between them, both being engaged in commerce. This would be true whether they were in actual or potential competition with each other and even though the new corporation was formed to create a wholly new enterprise. Realistically, the parents would not compete with their progeny....

If the parent companies are in competition, or might compete absent the joint venture, it may be assumed that neither will compete with the progeny in its line of commerce. Inevitably, the operations of the joint venture vill be frozen to those lines of commerce which will not bring it into competition with the parents, and the latter, by the same token will be foreclosed from the joint ventures market.

378 U.S. at 173 (1964).

10. Ibid.

11. Id. at 177 . 
the joint venture violative of section 7 of the Clayton Act, he argued that Pennsalt and Olin had joined forces to share the market on the "eve of competitive projects," and that the case was therefore the same in principle as Addyston Pipe \& Steal which held a cartel illegal per se. ${ }^{12}$ He cited Timlicn ${ }^{14}$ for the proposition that the elimination of competition could not be justified merely because it occurred through a joint venture. Justice Douglas' only recognition that the rigid per se analysis adopted here required reconciliation with his position in White Motor came in a footnote in which he remarked simply that White Motor had concerned "a vertical arrangement involving a territorial restriction whose validity we concluded could be determined only after a trial, not on a motion for summary judgment."14 If this was intended to reconcile Douglas' position in the two cases, it hardly seems adequate to the task. Since he had not explained in White Motor any more than in PcnuOlin why a vertical arrangement might be different from a horizontal one, the footnote in the latter sheds no light on the apparent inconsistency of Douglas' positions in the two cases. ${ }^{10}$

In seeking a tenable resolution of the law's conflicts and confusions it will be necessary to do more than state an economic theory, for antitrust is law as well as economics, and law has its own claims, its own tradition and discipline. The lawyer, unlike the economist, is forced by his craft to do more than understand and describe. He must assess alternatives in order to decide what can sensibly be done about particular situations. He must, in addition, determine what rules can properly be laid down for the future, which means that he must be aware not merely that the facts of the industrial and commercial world set limits to worthwhile remedies and so to stibstantive law, but also that additional limits for doctrine are set by the processes of warning, adjudication, and enforcement. Even in a predominantly common law field stuch as antitrust the courts should not of course write afresh with each case, for the common law itself places great value upon continuity of doctrine. Change, in all but exceptional cases, is preferably kept within a given field's existing conceptual framework. The Sherman Act's rule of reason, however, as Chief Justice White made plain in Standard Oil and American Tobacco, ${ }^{10}$ rather uniquely contains within itself a concept of the desirability and the means of change and reform. And, finally, the case law is entitled to respectful attention

12. Addyston Pipe \& Steel Co. v. United States, 175 U.S. 211 (1899), cited by Mr. Justice Douglas, id. at 178, 180.

13. Timken Roller Bearing Co. v. United States, 341 U.S. 593 (1951).

14. 378 U.S. at $177-78$ n.1.

15. If a difference in prior law could be perceived, it may be that vertically imposed price-fixing agreements were viewed even more strictly than the horizontal variety. Ste Oaks \& Krane, Resale Price Maintenance by an Integrated Firm: The McKesson \& Robbins Case, 24 U. CHI. L. Rev. 533, 533-34 (1957). The fact that White Motor arose on appeal from a grant of summary judgment would not seem in Douglas' view to distinguish it from his analysis of Penn-Olin since the question he was discussing in both cases was the applicability of the per se rule.

16. See text following note 84 infra. 
as a possible source of wisdom about policy. Economists have not yet by any means completely worked out the application of their theories to all forms of market behavior. One must always be alert to the possibility that the distinctions and categories of the law, often poorly articulated and seemingly divorced from economic theory, may nevertheless reflect a strong practical sense of and feeling for the phenomena with which the courts have dealt. The law, therefore, may sometimes have suggestions to make to economics, and these ought not to be overlooked.

This article contains two major sections. The first attempts, through an examination of key cases, to identify the main themes of policy and of economic reasoning in the judicial development of the rule of reason. It also assesses the fitness for the law of the policies discerned and suggests that the sole appropriate value in this field of antitrust is the maximization of consumer want satisfaction. The article's second section attempts an economic analysis of the more common forms of price fixing and market division in an effort to suggest the considerations which should govern their legality or illegality.

\section{Main Themes In the Rule of Reasow}

In one sense the attempt to isolate and describe the main themes of the rule of reason involves a considerable element of arbitrariness, for it is not to be supposed that any of the judges whose opinions are to be discussed possessed fully articulated antitrust philosophies which are discoverable through close reading. The problems set were often intrinsically difficult under any approach and there was not unanimity as to whether the law had wholly economic ends or contained a strong admixture of other social and political considerations. The main judicial avenues of approach have thus not displayed sharply defined edges. Different judges - and sometimes the same judge at different times - have seemed to employ different theoretical apparatuses.

Recognizing, then, that any classification is to some extent an artificial construct, it still seems useful and legitimate to attempt to arrive at one. The cases that came before the courts forced them to make a number of basic distinctions, and the necessary implications of those distinctions, whether fully present in the minds of their authors or not, may now be discerned and may fairly be said to constitute distinct themes or approaches. That theme which is here identified as the main tradition of the rule of reason has as its strength and dominant characteristic an overriding concern with economic values, that is, with the maximization of consumer want satisfaction through the most efficient allocation and use of resources. The primary achievement of this tradition has been the adoption by the law of a rule of per se illegality for cartel agreements. ${ }^{17}$ Deviant strains in the law have usually been charac-

17. The word "cartel" is used in this article to mean an agreement or arrangement which merely eliminates competition and does not assist in the creation of efficiency. 
terized by a willingness to give operative significance to conflicting aims, such as the welfare of particular producer groups. Failure by both courts and commentators to recognize the existence of separate themes, defined roughly by the values which they implement, has been responsible for much of the confusion for which antitrust law is so justly noted.

Judicial confusion is not entirely to be decried, however. It has been an important, functioning part of antitrust. Without it the various dogmas and platitudes which occupy so much of the field might have done more damage in actual results than they have. Confusion exists within each antitrust strain -for none of them have achieved entire philosophical consistency-and also between the strains. The latter type of confusion has been especially useful. A judge accustomed to working within the dominant stream of antitrust theory, that which stresses economic values and the importance and the breadth of the per se rules, may be forced to judge an agreement valid under the basic policy goals of the main tradition but obviously not capable of being handled satisfactorily within its confining verbal formulae. Antitrust's doctrinal confusion allows the judge to rely, without any real explanation, upon a precedent arising from a wholly different theory - one which in the ordinary case he would utterly ignore. This tactic accounts for the accordion-like career of Justice Brandeis' Chicago Board of Trade opinion. When the rigidities of the per se rule seem semantically applicable but also somehow inappropriate the court is likely to rediscover Brandeis' vague dicta as the essence of the rule of reason. Between times, the case is treated as precedent only for the legality of a minor regulation of trading on an organized exchange. Though confusion has thus served antitrust well, giving it the flexibility made necessary by the individual inadequacy of its various theories, the price has been the sacrifice of predictability. Antitrust's need now is coherent generalization which will combine the needed degree of flexibility and predictability.

The decisions of the law's formative period concerning price fixing and market division are nowadays usually either ignored altogether or treated as mere history. Yet a close examination of them as doctrine is rewarding. One of the rewards is the discovery that the conventional view of certain of these cases is apparently mistaken and that in this field re-evaluation is due both of judicial reputations and of the history of doctrinal development.

More importantly, the cases of the first several decades of the Act merit careful restudy because the courts were then forced to confront and debate the law's fundamental policy questions in a more explicit fashion than has been common since. Lacking any real guidance from either the language of the statute or its legislative history, particularly on the topics under discussion here, the courts were forced themselves to legislate in a broad manner and to discuss what consistent and useful policy might be. Analysis of the opinions they wrote against the factual settings with which they had to deal thus reveals something of the inherent nature of the problems with which any body of rules in this field must cope. 


\section{The Establishment of the Main Tradition}

The main tradition of antitrust with respect to price fixing and market division was shaped in the law's formative period primarily by three men: Justice Peckham, who wrote the Supreme Court's earliest decisions dealing with price fixing and market divisions; Judge Taft who, as a court of appeals judge, wrote one of antitrust's most suggestive opinions; and Chief Justice White who, after a false start in dissenting from Pechham's first opinions, recovered to write the 1911 Standard Oil and American Tobacco decisions that gave the name "rule of reason" to a position that was essentially Peckham's. Justice Harlan appears also to have been in this tradition, though his inability to articulate his distinctions or to grasp those made by others caused considerable unnecessary confusion about both.

Any assessment of the successes and failures of these jurists, and of those of different views, such as Justice Holmes and Justice Brandeis, whose work will be discussed separately, must take into account the difficulties they faced. One frequently hears talk of the original meaning of the Sherman Act or of the intent of Congress in enacting that law, but it can hardly be stressed too much that, with respect to the Sherman Act, and particularly with respect to loose arrangements of the sort under discussion, such talk of legislative intent is more than usually foolish. Congress simply had no discoverable intention that would help a court decide a case one way or the other. At least some of the legislators apparently thought they were enacting the common law. ${ }^{18}$ The language of the first section of the Act employed terms taken from the common law, pronouncing unlawful, "Every contract, combination in the form of trust or otherwise, or conspiracy, in restraint of trade or commerce." The common law, however, proved of no significant help because it had no unitary body of doctrine to which a Sherman Act court could look to find the contours of the new statute. The common law precedents were diffuse and contradictory, differing from jurisdiction to jurisdiction and often inconsistent even within the same jurisdiction. ${ }^{19}$ The common law concerning restraints of trade, moreover, was rooted in very different social policy from any which could be relevant to the Sherman Act. The preservation of competition was certainly one of the major policies motivating the passage of the Sherman Act. But the common law on the topic began, so far as any reported case shows, early in the fifteenth century,,$^{20}$ a time when the English courts can hardly be supposed to have been aggressively forwarding the idea of competition as the regulator of markets. The rule against contracts in restraint of trade, by which the early common law meant agreements not to practice a trade, was designed primarily to prevent a man from trading away his liveli-

18. See Dewey, The Common-Law Background of Autitrust Policy, 41 VA. L. Rev. 759 (1955).

19. See Dewey, supra note 18, and Letwin, The English Common Law Concersing Monopolies, 21 U. CHI. L. REv. 355 (1954).

20. Dyer's Case, Year Book, 2 Hen. V., vol. 5, pl. 26 (1415). 
hood in a society where extensive governmental and guild restrictions might prevent him from finding comparable employment.21

Centuries later, some common law courts, particularly in American jurisdictions, did develop concern for competition, 22 but their efforts were too sporadic and too heavily contradicted by other decisions to develop any doctrine that could be identified as "the" common law and made applicable to the Sherman Act. Counsel in the early cases were able to cite common law precedent to support virtually any position they took. Probably for this reason, as well as the hopelessly anachronistic nature of any attempt to apply concepts evolved out of a medieval guild society to a modern commercial nation, the Sherman Act courts have never paid much more than lip service to the common law. Instead, uninstructed by the statutory text, the legislative history, or the common law, the first Sherman Act courts were required by an in. scrutable but urgent legislative command to create useful social policy. ${ }^{33}$ They

21. Letwin, supra note 19, at 374-75. Parker, C.J., in Mitchel v. Reynolds, (1711) 1 P.Wms. 181, 24 E.R. 347, 350, stated that a major objection to covenants not to competc had been "the mischief which may arise from them, 1st, to the party, by the loss of his livelihood, and the subsistence of his family; $2 d l y$, to the publick, by depriving it of an useful member." For a collection of materials on the guild system and its impact on this area of the law, see Handler, Cases and Materials on Trade Regulation 49-59, 102 n.1 (1937).

22. See, for example, the cases discussed by Judge Taft in United States v. Addyston Pipe \& Steel Co., 85 Fed. 271, 288-91 (1898).

23. A contemporary commentator discussing the application of the new statute to monopoly offered a conclusion which seems applicable to the entire statute as of the time he wrote: "But one conclusion, upon the whole, can be reached. The Act is necessurily vague, because, in men's minds, the evil dreaded is vague, and like words, thercforc, have been used to express it." Dana, "Monopoly" Under the National Antitrust Act, 7 Hanv. L. REv. 338, 355 (1894).

It seems clear that the congressional debates provided few firm guidelines to the courts who had to build a law about agreements fixing prices or dividing markets. Certainly the early cases did not explicitly rely upon any cited congressional determinations. The need to preserve competition was a primary theme in the legislative deliberations, but values other than competition as a means of protecting consumers - such as the freedom of small entrepreneurs and the limitation of essentially governmental economic power in private hands - were also voiced by the Sherman Act's proponents in Congress. In many cases these values would lead to the same decision as would concern for consumers, and hence would be entirely superfluous to decision making. In other cases, however, they would require different results and Congress provided no means of resolving the conflict. It was not at all clear, in any event, that most of the legislators regarded such values as independent factors to be weighed by the courts rather than as desirable by-products which would often automatically follow from the preservation of competition. For a genteral description of the policy considerations mentioned in the Congress that enacted the Sherman Act and the general muddiness of the legislative intent, see THoreLLr, THE FEDErAl AntrTrust Policy 225-32 (1954).

Even allowing for the truth in Justice Frankfurter's remark that "the fair interpretation of a statute is often 'the art of proliferating a purpose,' . . . revealed more by the demonstrable forces that produced it than by its precise phrasing," Universal Camera Corp. v. NLRB, 340 U.S. 474, 489 (1951), the task facing the courts with respect to section 1 of the Sherman Act was arguably unduly legislative in nature. The problem of the proper response of the courts to such a problem is discussed at pages $829-47$ infra. 
proceeded to discharge this delegated function with what appears in retrospect to have been considerable skill.

\section{Justice Peckham's Rule of Reason}

Despite the near universal opinion that Chief Justice White fathered the modern rule of reason in his 1911 Standard Oil 24 and Ameriean Tobacco 25 opinions, ${ }^{26}$ a careful reading of Justice Peckham's opinions indicates that the honor of paternity belongs instead to him. It is difficult to account for the common assessment of Peckham as a mere literalist who advocated an unworkably rigid interpretation of the statute ${ }^{27}$ except as due to an excessive reliance upon verbal formulations. Peckham's seemingly literal reading of the statute was probably a tactic in his debate in 1897 with White over the construction of the new statute. White then advocated a position very different from that he espoused as the "rule of reason" in 1911. The point at issue in the Peckham-White debate, though White seems then to have misunderstood it, was not whether the Act should be flexible or rigid but by what criteria its flexibility should be controlled.

The occasion for this debate was the Trans-Missouri decision, ${ }^{23}$ the first case in which the Supreme Court was called upon to apply the Sherman Act to a price-fixing agreement. The government had brought a bill to enjoin the Trans-Missouri Freight Association and eighteen member railroads from agreeing upon rates and other terms of service upon designated rail traffic.:0 The case was complicated by the requirement of the Interstate Commerce Act, which it was not suggested defendants had violated, that all railroad rates, however arrived at, be "reasonable and just."30 At the hearing on the bill and answer defendants' allegations that they had charged only reasonable rates were taken as true. The circuit court dismissed the bill, holding that, though contracts which eliminated healthy competition were to be condemned, those which "go to the extent only of preventing unhealthy competition, and yet at the same time furnish the public with adequate facilities at fixed and reasonable prices and are made only for the purpose of averting personal ruin" are lawful. ${ }^{31}$ A two-judge majority in the Circuit Court of Appeals affirmed the

24. Standard Oil Co. of New Jersey v. United States, 221 U.S. 1 (1911).

25. United States v. American Tobacco Co., 221 U.S. 106 (1911).

26. This view is so general in the literature today that citation of individual statements to that effect seems not only superfluous but misleading.

27. See, for example, Handrer, Antrtrust in Perspective 4-7 (1957).

28. United States v. Trans-Missouri Freight Ass'n, 166 U.S. 290 (1897).

29. The agreement allowed individual roads to charge rates below those set by the Association, but provisions for advance notice of rate reductions, collective reductions by other roads to meet individually lowered rates, and similar procedures, seemed calculated to discourage rate cutting.

30. 24 Stat. 379 (1887).

31. United States v. Trans-Missouri Freight Ass'n, 53 Fed. 440, 451 (C.C.D. Kan. 1892). The judge quoted a Michigan decision with approval: "The public is quite as much interested in the prosperity of its citizens in their various avocations as it can possibly be in their competition." Id. at 452. 
dismissal, agreeing that relevant precedent supported "the proposition that it is not the existence of the restriction of competition, but the rensonableness of that restriction, that is the test of the validity of contracts that are claimed to be in restraint of trade."32 This reasonable-price interpretation of the statute's meaning represented at that time a not uncommon view of federal judges who had occasion to apply the law, ${ }^{33}$ and seems very nearly to have carried the Supreme Court itself. Peckham led the majority in a five-to-four decision holding the dismissal of the bill error. ${ }^{34}$ White and the minority apparently accepted the railroad's argument that only unreasonable restraints were outlawed by the statute and that reasonableness was defined by the reasonableness of the rates they had agreed upon. Since the Interstate Commerce Commission had found the rates reasonable, the argument went, defendants' restraint of trade was necessarily reasonable and the government's bill properly dismissed.

Peckham's "literal" reading of the statute - his insistence that the Act could not be read to legitimate a category of "reasonable" restraints since it outlawed "every" restraint - appears to have been largely a tactic to defeat White's version of the law, not the result of a simple-minded application of the statutory language. ${ }^{35}$ Certainly Peckham was not opposed to flexibility

32. United States v. Trans-Missouri Freight Ass'n, 58 Fed. 58, 72 (8th Cir. 1893). The opinion stated that while contracts whose main purpose was the suppression of competition might be illegal, it did not follow that it was unlawful to make agreements whose main purpose was "to so regulate competition that it may be fair, open, and healthy, and whose restriction upon it is slight, and only that which is necessary to accomplish this purpose." Id. at 69.

The dissenting judge agreed that this was the general rule but contended that a stricter one applied to railroads. He attemped a distinction between private parties engaged in such pursuits as "the manufacture or sale of lumber, dry goods, or other like articles," to whom the majority's rule would apply, and two classes of persons to whom a more stringent rule forbidding all agreements restricting competition applied, namely private partics dealing in "staple commodities" or "articles of prime necessity," and corporations, such as railroad companies, engaged in work of a public nature. Id. at 87. This judge identificd corporations engaged in work of a public nature as those whose duties "require in their performance the exercise of the sovereign right of eminent domain" but did not indicate how one might distinguish a staple commodity or article of prime necessity from such frivolities as dry goods and lumber. $I d$. at 86 .

33. See, for example, in addition to the lower court opinions in Trans-Missouri, the opinions in Dueber Watch Case Mfg. Co. v. E. Howard Watch \& Clock Co., 55 Fed. 851 (C.C.D.N.Y. 1893), aff'd, 66 Fed. 637 (2d Cir. 1895); and Gibbs v. McNeeley, 102 Fed. 594 (C.C.D. Wash. 1900), rev'd, 118 Fed. 120 (9th Cir. 1902). Among the distinctions suggested in the Dueber Watch Case opinion in the Court of Appeals were the reasonableness of the price fixed, whether the goods affected were articles of prime necessity, whether the parties had market power, whether the restraint was general or partial, and whether the parties merely bound themselves or tried to force others to agree.

34. Besides Peckham, the majority consisted of Chief Justice Fuller and Justices Harlan, Brewer, and Brown. The minority consisted of Justices White, Field, Gray and Shiras.

35. The contribution of the government's argument to Peclkham's solution is problematical. The government's brief urged that the Sherman Act was not controlled by the common law and that Congress had "imposed on the courts no duty of inquiry as to rea" 
in application of the law, for, as will be seen, he introduced a sophisticated power of discrimination into the law in his definition of the term "restraint of trade." His real objection to White's test of "reasonableness" was based on the criteria that test, as White and the lower court judges framed it, would have imported into the Act. ${ }^{36}$ To avoid that construction it was an obvious maneuver for Peckham to resort to the statutory text:

sonableness or justifiability, but condemned all restraints. ... [T] [he prevention of competition, entire or partial, is a restraint of the trade or commerce in which it exists." Brief for the United States, United States v. Trans-Missouri Freight Ass'n, 166 U.S. 290 (1897), p. 31. Taken literally, this view would require a complete per se rule against the climination of competition. Later the brief seemed to offer a less drastic approach, arguing that the principles relating to monopoly were relevant and that one of monopoly's chici evils was the destruction of competition and the consequent prevention of the oferation of ordinary commercial causes upon prices. This seems to call for illegality only when the parties control the market. Id. at 38 . The brief suggested, in a passage adumbrating Brewer's concurring opinion in Northerm Securitics, sce note 112 infra, that an agreement eliminating competition between railroads was not only the same wrong as ordinary trusts and combinations but was "in fact more harmful in effect, though the same in principle, because it is easier to stifle competition which is limited by natural laws. When but little competition is possible, such as there is becomes all the more important and should be the more jealously guarded." Id. at 39. The brief argued the case also under the alternative theory that the common law did control the statute and suggested a formulation resembling that later adopted by Judge Taft. See text accompanying notes 64-82 infra.

36. Defendants' briefs may only have increased Peckham's doubts about the possibility of using the common law to give meaning to the statute. In arguing that the Sherman Act, if it incorporated the common law, was too vague to be constitutional, anpellees said:

The truth is that the term "contracts in restraint of trade" does not designate any" class of unlawful contracts, but only a class of contracts concerning the legalily of which questions arise. Some of them are unlawful while others are not; and whether any particular one is unlawful depends upon whether or not it is contrary to public policy. This is the only test.

Brief for Appellees, p. 33. But then, arguing in the alternative under the theory that the common law was controlling, appellees said that the test was reasonableness, which means "what is agreeable to reasont." Id. at 65 . What was "agrecable to reason" at common law, and hence under the statute, turned out to be both such subsidiary contracts as the agrcement not to compete by the seller of a business and those in which the restraint itsclf was the main object, including "those contracts the object of which is to restrain or regulate competition." Id. at 69. The latter fell into three categories: (1) Contrets between persons dealing in prime necessities which from natural causes are limited in supply (viewed strictly by the law); (2) contracts between persons making or dealing in ordinary commodities whose supply can be increased by others if the price is kept high (Here, the law regards the agreement as innocent if it appears that the purpose was simply to maintain fair and reasonable prices. But even here the agreement will be regarded with greater jealousy if it relates to a commodity which is a prime necessity of life.); and (3) combinations between persons exercising public franchises with the view of restricting or regulating competition. (Here the law fixes the price of the service rendered in the absence of an agreement as to what is reasonable.) Id. at 69-70.

Applying the third category to the case before the court, the brief contended:

The question, therefore, turns upon the nature and results of competition in the business of railroad transportation; what the benefits of such competition are, what evils, if any, are incident to it, whether it is competent to the parties engaged in it as 
When, therefore, the body of an act pronounces as illegal every contract or combination in restraint of trade or commerce among the several States, etc., the plain and ordinary meaning of such language is not limited to that kind of contract alone which is in unreasonable restraint of tracle, but all contracts are included in such language, and no exception or limitation can be added without placing in the act that which has been omitted by Congress. ${ }^{37}$

He concluded that an agreement fixing rates was a contract in restraint of trade and, therefore, was illegal regardless of the supposed reasonableness of the rates established.

Peckham was by no means content, however, to rest his construction of the statute entirely upon its text. He also argued persuasively against a reasonableprice standard because "the subject of what is a reasonable rate is attended with great uncertainty" 38 so that it would be "exceedingly difficult to formulate even the terms of the rule." Moreover, "even after the standard should be determined there is such an infinite variety of facts entering into the question of what is a reasonable rate" that the effort of making a case would be so

rivals to seek by voluntary agreement to avoid such evils, and whether the means employed in the present instance are reasonably calculated to repress such cvils, or to restrict the benefits of competition.

\section{Id. at 71-72.}

Though this test seemed to require that every price-fixing case be conducted by undertaking a complete industry study and be concluded with a legislative judgment by the court, counsel really had a simpler solution to offer, since, they contended, reasonable prices were assured in this industry by the law which required rates to be reasonable and in other industries by the fact that any attempt to increase prices to an unreasonable point would attract new capital, increase the supply, and lower the price. Id. at 115-16. This seemed to mean that all agreements to fix prices would be lawful except in those rare cases in which the supply of the product was absolutely fixed. Having been forced through this welter of categories and metaphysical distinctions to learn that almost all cartels are lawful, Peckham and the other justices of the majority might justifiably have concluded that the common law did not have a great deal to offer the Sherman Act.

37. 166 U.S. 290, 328 (1897).

38. What is the proper standard by which to judge the fact of reasonable rates? Must the rate be so high as to enable the return for the whole business done to amotnt to a sum sufficient to afford the shareholder a fair and reasonable profit upon his investment? If so, what is a fair and reasonable profit? That depends sometimes on the risk incurred, and the rate itself differs in different localities: which is the one to which reference is to be made as the standard? Or is the reasonablencss of the profit to be limited to a fair return upon the capital that would have been sufficient to build and equip the road, if honestly expended? Or is still amother standard to be created, and the reasonableness of the charges tried by the cost of the carriage of the article and a reasonable profit allowed on that? And in such case would contribution to a sinking fund to make repairs upon the roadbed and renewal of cars, etc., be assumed as a proper item? Or is the reasonableness of the charge to be tested by reference to the charges for the transportation of the same kind of property made by other roads similarly situated? If the latter, a combination among such roads as to rates would, of course, furnish no means of answering the question. 166 U.S. 290, 331-32 (1897). 
enormous as to defeat the action. ${ }^{39} \mathrm{He}$ effectively demonstrated, in fact, that the question of what is a "reasonable" rate is a foolish one for a court to ask because the only meaningful answer is the rate set by competition. ${ }^{40}$ Pechham made yet another policy argument against a reasonable-price standard, stating that the mere power to affect prices, when achieved by agreement, should be illegal because it might be used not only to raise prices but to lower them to the detriment of small competitors of the cartel.41

In Trans-Missonri Peckham gave a brief but highly suggestive indication of his "rule of reason" when, though he insisted that every restraint of trade was illegal, he indicated that

A contract [by the vendor of business property not to enter into the same kind of business for a certain time or within a certain territory] which is the mere accompaniment of the sale of property, and thus entered into for the purpose of enhancing the price at which the vendor sells it, which in effect, is collateral to such sale, and where the main purpose of the whole contract is accomplished by such sale, might not be included within the letter or spirit of the statute in question. ${ }^{2}$

Since this passage indicated that a contract clearly classified as one "in restraint of trade" at the common law might not even be "within the letter" of the statute, it should have served notice that Peckham was reinterpreting that familiar phrase to fit the different role of the statute. ${ }^{23}$

White, in his dissenting opinion seemed, as did many commentators afterward, to miss the significance of Peckham's remark and to suppose that it was really only a rather fatuous blunder that revealed the emptiness of Peckham's attempt at a "literal" construction of the statute. White asked rhetorically,

But how, I submit, can it be held that the words "every contract in restraint of trade" embrace all such contracts, and yet at the same time it be said that certain contracts of that nature are not included? The asserted exception not only destroys the rule which is relied on, but it rests upon no foundation of reason. ${ }^{44}$

39. [A]ny individual shipper would in most cases be apt to abandon the effort to show the unreasonable character of a charge, sooner than hazard the great expense in time and money necessary to prove the fact, and at the same time incur the ill will of the road itself in all his future dealings with it. To say, therefure, that the act excludes agreements which are not in unreasonable restraint of trade, and which tend simply to keep up reasonable rates for transportation, is substantially to leave the question of reasonableness to the companies themselves.

166 U.S. 290,332 (1897).

40. Id. at 339. Peckham utterly ignored White's thrust that, if the reaconableness of rates were impossible of ascertainment, a very odd light was cast upon a recent judgment of the Court upholding an ICC determination that certain rates were unreasonable. Id. at 373. Perhaps his silence suggested that it was one thing when Congress had legislated an essentially nonsensical standard which the Court must perforce apply and quite another when the Court was free to choose.

41. Id. at 323.

42. Id. at 329 .

43. Elsewhere in the opinion it was suggested that the term might have a different meaning in the statute. $I d$. at 313 .

44. Id. at 352 . 
Yet it should have been possible to see, even in Trans-Missouri, that Peckham was redefining "restraint of trade" to refer to the elimination of competition in the general market. This represented a groping toward a standard - far more sophisticated than White's fuzzy notion of "reasonable" prices - capable of separating two very different classes of agreements eliminating competition: thus, the contrast between an agreement collateral and subordinate to the sale of property and an agreement between railroads to set rates. One was probably perceived as very unlikely to affect competition generally; the other as almost certain to. This, and other reasoning in the opinion, shows that Peckham accepted the preservation of competitive markets as a main purpose of the statute. ${ }^{45} \mathrm{He}$ appears to have framed a rule very much like that of per se illegality for cartel agreements. He said of the agreement between the railroads that "there can be no doubt that its direct, immediate, and necessary effect is to put a restraint upon trade or commerce as described in the act" and that it was therefore illegal "no matter what the intent was on the part of those who signed it."46

The preservation of competition was not the sole value Peckham saw in the Act, however. As already noted, he feared the power of a combination to set low prices as much as its power to set high prices. The basis for this fear was concern for small traders and also, perhaps, a belief that the statute's goals could properly include the social and political as well as the economic wellbeing of the nation. ${ }^{47}$ Peckham here sounded complex themes which echo

45. Thus, when meeting the argument that, because the railroads had the right to charge reasonable rates under the Interstate Commerce Act, they had the right to ayree with competing roads to maintain such rates, Peckham said that what one road might do was radically different from agreeing with competing roads to keep rates up. "Competition will itself bring charges down to what may be reasonable, while, in the case of an agreement to keep prices up, competition is allowed no play." 166 U.S. 290, 339 (1897). Though in Trans-Missouri he never explicitly defined "restraint of trade" as a cartel agreement to eliminate competition from the general market place, that was the working concept he kept coming back to.

46. Id. at 342 .

47. High prices Peckham feared for the sake of the public, but he was not consistent about his reasons for fearing low prices. He argued that business or trading combinations may even temporarily, or perhaps permanently reduce the price of the article traded in or manufactured, by reducing the expense inseparable from the running of many different companies for the same purpose. Trade or commerce under those circumstances may nevertheless be badly and unfortunately restrained by driving out of business the small dealers and worthy men whose lives have been spent therein, and who might be unable to readjust themselves to their altered surroundings. Mere reduction in the price of the commodity dealt in might be dearly paid for by the ruin of such a class and the absorption of control over one commodity by an all-powerful combination of capital.

166 U.S. at 323.

In thus preferring a society of "small dealers and worthy men," even if it were necesa sary to forego lowered costs and even permanently lowered prices to retain them, Peckham foreshadowed Justice Brandeis and the modern developments of the policies he advocated. See text at pages $815-28,832-33$ infra.

Peckham distinguished, perhaps not entirely consistently, between the dislocations and personal misfortunes which were the "inevitable accompaniment of change and improve- 
through antitrust to this day. It is important that these themes should have been raised in the first price-fixing case in the Supreme Court, for that establishes their ancient lineage in antitrust, and that Peckham gave them voice, for that shows that not even antitrust's main tradition has been entirely consistent. The per se rule and concern for competition, as will be seen, are likely to prove incompatible with an attempt to further social and political values in the same statute, if the latter values are given operative significance. ${ }^{48}$ Their expression together in this opinion demonstrates that anti-trust's lack of policy clarity is as old as the statute. Peckham belongs in the main tradition, however, because though he expressed other values, he nevertheless employed a per se rule keyed to the economic values of competition.

Of White's dissent very little more need be said. He argued, as already noted, that the Act employed a reasonable price standard. He did not suggest how a reasonable price was to be identified. Such a rule, uniformly applied, would have permitted unlimited cartelization with judicial supervision of price levels. White supported his position, however, by arguing that a law which struck down all contracts which restrained trade or the freedom of traders regardless of their reasonableness would outlaw "all those contracts which are the very essence of trade, and would be equivalent to saying that there should be no trade, and therefore nothing to restrain." 49 He thus lumped together the main contending themes of the rule of reason: the idea that some contracts are necessary to trade, though they may also eliminate some amount of competition; and the very different notion that some general suppression of competition might be desirable in itself. That he was prepared to have the Sherman Act judge the latter as well as the former is shown by his contention that Peckham's reading of the statute would forbid combinations of working men to obtain increased wages or shorter hours of labor. He noted that combinations of laborers had only been excepted from the common law prohibition of contracts or combinations in restraint of trade "either by statutory exemption

ment" (he cited the change from stage coaches and canal boats to railroads, the clange from hand labor to machinery, and from machines operated by hand to those operated by steam) and those "effected by combinations of capital whose purpose in combining is to control the production or manufacture of any particular article in the market." Id. at 323. But again he turned to the damage that might be done by low prices:

[I]t is not for the real prosperity of any country that such changes should occur which result in transferring an independent business man, the head of his establishment, small though it might be, into a mere servant or agent of a corporation for selling the commodities which he once manufactured or dealt in; having no voice in shaping the business policy of the company, and bound to obey orders issued by others.

Id. at 324.

Peckham thus vacillated between fear of the power of a combination to restrict output and raise prices and fear of the power of a combination to achieve efficiencies and lower prices. The result, in cartel cases at least, was to lead him to denounce the mere existence of power to fix prices achieved by agreement of competitors.

48. See text at page 838 infra.

49. 166 U.S. at 351 . 
therefrom, or by the progress which made reason the controlling factor on the subject." 50 This implied that courts as well as legislatures can decide what producer groups are to be preferred to consumers.

White seems, therefore, to have been willing for courts, in determining reasonableness under the Sherman Act, to make major policy judgments of a sort usually reserved for the legislature. This was something more than the courts were forced to do in any event by the vagueness of the Sherman Act, for he seemed to envision not the evolving of a firm set of criteria which Congress could then examine once and accept, modify, or reject, but rather a continuing process of choice between social philosophies by judges, a continuing determination of whether competition or cartelization was desirable in the particular case, and a continuing regulation of cartel behavior. This, apparently, was what White meant in 1897 by the "rule of reason." 1 His differences with Peckham were clearly fundamental, though perhaps not fully grasped on either side, and the narrow victory of the latter in the TransMissouri case probably had immense importance to the future evolution of the law.

That Peckham was not committed to an unworkably broad per se approach, but was in fact employing a rule of reason, though he did not of course use that term, became still clearer in his opinion the following year in the Joint Traffic case..$^{52}$ The case involved a railroad rate-fixing agreement indistinguishable in principle from that declared illegal in Trans-Missouri. ${ }^{53}$ This fact dic-

50. Id. at 356 .

51. It is sometimes suggested that White's dissent in Trans-Missouri should be interpreted as doing no more than making a sort of primary jurisdiction point: the I.C.C. having held the fixed rates reasonable under the Interstate Commerce Act, it was improper for the courts to hold them invalid under the Sherman Act. Under this view White's dissent really expressed no general construction of the Sherman Act. This interpretation seems unconvincing, however, particularly since White attacked the application of Peckham's rule to non-railroad situations as likely to prove disastrous and insisted upon the necessity of a rule of reason in those cases as well. It is true that he did not specify what the rule of reason should be in other cases but he accepted the reasonable rate argument in the case before him and did not indicate that this was restricted to that case. Rather the presence of the ICC determination appeared to be regarded merely as a fortuitous means of arriving at reasonableness in that particular situation. This view is strengthened by White's failure to disavow the lower court interpretations of reasonableness in the same case. These clearly envisaged application of the reasonable-price test to all industries. Another piece of evidence pointing in the same direction is that subsequently in Addyston Pipe \& Steel Co. v. United States, 175 U.S. 211 (1899), Peclham said that even if reasonableness of price were a defense the prices fixed there were unreasonable. I $d$. at 235. (This was not inconsistent with Peckham's general position on the reasonable price defense because it was uniquely possible in Addyston to make such a finding. See note 79 infra.) White joined the majority opinion. It seems quite possible that Peckham included the point about unreasonableness of prices, otherwise unnecessary in his interpretation of the law, to bring along the Trans-Missouri dissenters.

52. United States v. Joint Traffic Ass'n, 171 U.S. 505 (1898).

53. The agreement, between thirty-one railroads comprising most of the lines between Chicago and the Atlantic coast, was described in its preamble as designed "to establish 
tated defense counsels' tactics: a frontal assault upon the rationale of TronsMissouri. Defendants contended that the reading there given the statute would outlaw the most ordinary and indispensable contracts and consolidations. This had been a main point of White's dissent in the prior case and perhaps counsel hoped to detach at least one member from the five-man majority by spelling out the supposed implications of their prior decision. The majority held firm, however, and again Peckham wrote the opinion. He listed the transactions defendants said his reasoning would make unlawful: (1) "[T] he formation of a corporation to carry on any particular line of business"; (2) "a contract of partnership"; (3) "the appointment by two producers of the same person to sell their goods on commission"; (4) "the purchase by one wholesale merchant of the product of two producers"; and (5) "the lease or purchase by a farmer, manufacturer or merchant of an additional farm, manufactory or shop." Peckham answered, after pointing out that no such case was before the Court, that such transactions would be difficult to bring within the statutory category of "restraints of trade." Counsel had also said that Trans-Missouri's construction of the Act would render illegal "all organizations of mechanics engaged in the same business for the purpose of limiting the number of persons employed in the business, or of maintaining wages."ss Peckham, however, simply ignored this illustration in his rebuttal. Certainly the application of the statute to trade unions might have given him difficulty. ${ }^{\circ 0}$ Nevertheless, it seems significant that, of all the examples advanced by counsel, Peckham at least provisionally excluded from the category of "restraints of trade," as he defined it, those which were cases of consolidation or fusion, while the only example he listed but failed to comment upon involved the elimination of competition by agreement but lacked any other element of consolidation or fusion. ${ }^{57}$

and maintain reasonable and just rates, fares, rules and regulations on state and interstate traffic, to prevent unjust discrimination and to secure the reduction and concentration of agencies and the introduction of economies in the conduct of the freight and passenger service." Existing rates, fares, charges, and rules were reaffirmed but changes were to be recommended by the association's managers and the railroads were obligated to follow the recommendations so made. Individual roads could deviate only upon resolutions of their boards of directors. The machinery for such deviation as well as the agreement's direction to the managers upon receiving the required notice of such a resolution "to act promptly. upon the same for the protection of the parties hereto" were calculated to discourage failure to follow the recommendations.

54. 171 U.S. at 567-68.

55. Id. at 567 .

56. Trade unions are of course the same economic phenomenon as cartels, but they were not illegal in the United States at that time and it was certainly clear that in passing the Sherman Act Congress had not intended to destroy the union movement. For a narrative of the Court's difficulties in attempting to accommodate the existence of unions and collective bargaining to the contrary philosophy of the antitrust laws, see Grecosy, Lacos AND THE LAW ch. VIII (1946).

57. This distinction might have given Peckham difficulty in merger cases, and perhaps it explains his vote with Holmes in Northern Securities Co. v. United States, 193 U.S. 
The Joint Traffic opinion made it even clearer that by "restraint of trade" Peckham meant the elimination or suppression of competition in the general market, for, in defending the statute's constitutionality he asked rhetorically: "Has not Congress ... the power to say that no contract or combination shall be legal which shall restrain trade and commerce by shutting out the operation of the general law of competition?"58

Peckham's rule of reason, therefore, was one which outlawed those agreements whose purpose or effect was to suppress competition in the general market but to uphold those whose elimination of competition was collateral and incidental to another end the parties were pursuing. From the illustrations discussed, that other end which legitimated the elimination of competition between the parties seemed usually to be some form of consolidation or merger of their productive activities.

Peckham's rule, however, may not have been all of one piece. Mention has already been made of his suggestion in Trans-Missouri that the Sherman Act might embody social as well as economic policy. He did not there face the

197 (1904). But it is plausible to read the language of Joint Traffic as outlawing mergers under Section 1 if their purpose or effect was to restrain commerce:

[T] he statute applies only to those contracts whose direct and immedlate effect is a restraint upon interstate commerce. ... The effect upon interstate commerca must not be indirect or incidental only. An agreement entered into for the purpose of promoting the legitimate business of an individual or corporation, with no purpose to thereby affect or restrain interstate commerce, which does not directly restrain such commerce, is not, as we think, covered by the act, although the agrecment may indirectly and remotely affect that commerce.

171 U.S. at 568.

.The test of "direct and immediate" as opposed to "indirect and incidental" seems to be merely a rephrasing of the opposition of "direct, immediate, and necessary" to "collateral" or "incidental" which the Trans-Missoutri opinion sometimes used in place of the distinction between restraint and non-restraint.

58. Id. at 569. Throughout the Joint Traffic opinion "restraint of trade" is assumed to consist of stifling competition in the market. Thus, also in connection with constitutionality, Peckham framed the issue as Congress' power to prohibit, as in restraint of interstate commerce, an agreement entered into for the purpose of maintaining rates, and he explained that "The agreement affects interstate commerce by destroying competition and by maintaining rates above what competition might produce." Id. at 569.

Later, in Addyston Pipe \& Steel Co. v. United States, 175 U.S. 211 (1899), Peckham articulated still more clearly the distinction he had been making cver since Trans-Missouri. He stated that it was a restraint of trade, and therefore unlawful where the direct and immediate effect of a contract or combination among particular dealers in a commodity is to destroy competition between them and others, so that the parties to the contract or combination may obtain increased prices for themselves....

Id. at 244. But, paraphrasing Anderson, he said:

when it is seen that the agreement entered into does not directly relate to and act upon and embrace interstate commerce, and that it was executed for another and entirely different purpose, and that it was calculated to attain it, the agreement Ibid. would be upheld, if its effect upon that commerce was only indirect and incidental. 
question of which policy should take precedence where the two came into conflict. Perhaps, therefore, his talk of non-economic values was mere rhetoric, without operative significance in the law. That theme, however, recurred in Peckham's opinion in the Arderson case ${ }^{60}$ upholding an agreement by members of an association not to deal with non-members. Defendants, members of the Traders' Live Stock Exchange, were speculators at the Kansas City stockyards, buying cattle and then either reselling upon the same market or reshipping to other markets. They agreed not to deal with any other yard traders who were not Exchange members and not to deal with any commission merchant who dealt with a non-member. Peckham accepted the claim that the association had no explicitly pecuniary aims but was devoted to such ends as the improvement of standards of business integrity. The ultimate rationale of the decision is not entirely clear. Peckham mentioned, seemingly as determinative factors, that the Exchange was open to all yard traders who would abide by its rules and that there was a large market for cattle wholly apart from defendants. He did not discuss the problem that would exist if the Exchange expanded so that there was no important market outside its membership. Perhaps even then he would have found it lawful. But at times the main thrust of his reasoning appears to have been that the association was not aiming at the suppression of competition:

If an agreement of that nature, while apt and proper for the purpose thus intended, should possibly, though only indirectly and unintentionally, affect interstate trade or commerce, in that event we think the agreement would be good. Otherwise, there is scarcely any agreement among men which has interstate or foreign commerce for its subject that may not remotely be said to, in some obscure way, affect that commerce and to be therefore void. ${ }^{60}$

The decision may not, therefore, reflect a belief that some values, such as the improvement of business morals, justify the elimination of competition. A decision based upon such a belief would of course rest upon a standard indistinguishable from White's test of reasonableness which Peckham had emphatically rejected. It appears more likely that Peckham did not analyze an agreement to use only "ethical" business tactics (as defined by the interested parties) as an elimination of competition of the same sort as an agreement fixing prices. ${ }^{01}$

This view is consistent with Peckham's reference to the restraint in Anderson as "indirect." The test of "direct" and "indirect" in Anderson and the companion Hopkins case ${ }^{62}$ replaced the earlier dichotomy of restraint and non-

59. Anderson v. United States, 171 U.S. 604 (1898).

60. Id. at 616 .

61. This seems an error because an agreement not to compete in ways that the parties define as "unethical" is like an agreement not to compete in price in that its primary purpose and effect is to remove one form of competition between the parties without any compensating fusion of their productive efforts or other gain in efficiency.

62. Hopkins v. United States, 171 U.S. 578 (1898). 
restraint employed in Trans-Missouri and Joint-Traffic. ${ }^{03}$ Like the earlier test, that of direct and indirect was a means of distinguishing between agreements whose primary purpose and effect was the suppression of competition in the general market and those whose purpose was something else but which would, just as any economic behavior would, inevitably have some side effect upon the market.

Peckham, then, was an important figure in the development of the Sherman Act, which is to say, in the formation of basic anti-trust policy. He deserves a better reputation than he has been accorded. If he did not work ont a completely consistent and fully developed rule of reason, neither has anyone else, and Peckham made the attempt with no significant guidance either from Congress or preceding judicial tradition. He devised, nonetheless, a version of the statute whose distinctions were keyed to the policy of preserving competition in the general market while permitting those agreements and cooperative endeavors which are useful in the promotion of industrial and commercial effciency. His insistence that the statute, by outlawing "every" restraint of trade, did not enact the common law saved the Sherman Act from a stultifying effort to incorporate a body of confused and inappropriate precedent. His rejection of a reasonable-price standard of legality may have saved the statute from the futility of becoming a judicially-administered version of the National Industrial Recovery Administration. Given the enormous administrative difficulty of the task, the result of such a misstep would surely have been the effective retirement of the courts from the field, except perhaps for the occasional policing of conduct that seemed particularly predatory or "unfair." He this helped to prevent the statute from becoming a license to cartelize. Perhaps even more important, he helped to shape a statute which became, and for a long time remained, the politically potent symbol of the free and unregulated market. Whatever the shortcomings of his opinions and his articulation of their rationale, at a crucial point in antitrust history Peckham and the four justices who joined him made the right decision.

\section{Judge Taft: The Concept of Ancillarity}

After Trans-Missouri but before any additional clarification of its meaning by the Supreme Court, Judge Taft, as he then was, in his opinion for the Sixth Circuit in Addyston Pipe \& Steel, ${ }^{84}$ made an ambitious attempt to provide the Sherman Act with a workable formula.

63. In the Trans-Missoutri and Joint Traffic opinions Peckham had occasionally used phrases similar to "direct" and "indirect." See note 57 stpra. Perhaps the reason for shifting more consistently to the direct-indirect phraseology from that of restraints and nonrestraints was the awkwardness of denying that agreements known to the common law as in restraint of trade (such as the agreement not to compete collateral to the sale of a business) were restraints of trade under the Sherman Act. The Trans-Missouri phrasing seemed to contradict what every common lawyer knew, while that of Anderson, though the same in substance, defied no accepted categories of speech or thought.

64. United States v. Addyston Pipe \& Steel Co., 85 Fed. 271 (6th Cir. 1898). 
The case came up on the government's appeal from the circuit court's dismissal of its petition in equity charging six manufacturers of cast-iron pipe with an agreement to fix prices and divide territories. Defendants attempted to avoid the effect of Trans-Missouri by arguing that its strict rule applied only to quasi-public corporations such as railroads and that the statute applied a common-law test of reasonable prices to their agreement. Taft elected to sidestep the task of interpreting Trans-Missouri and to meet defendants upon the ground of the common law. It seems reasonable to suspect that he chose this more difficult toute because it gave him a way of joining in the dispute between the Peckham and White wings of the Supreme Court and offering, in the guise of an interpretation of the common law, and without a directness that might have seemed presumptuous in a lower court judge, a construction of the statute that avoided both what may have seemed to him Peckham's excessive rigidity and White's excessive fluidity.

According to Taft, the common law held void agreements in restraint of trade whose sole purpose was merely to restrain competition but upheld those which were merely subordinate to the accomplishment of another purpose. Admitting the existence of a contrary line of cases at the common law, and disposing of them as incorrect on policy grounds, he necessarily, though not explicitly, addressed himself to and refuted the rule of reason urged by White:

It is true that there are some cases in which the courts, mistaking, as we conceive, the proper limits of the relaxation of the rules for determining the unreasonableness of restraints of trade, have set sail on a sea of doubt, and have assumed the power to say, in respect of contracts which have no other purpose and no other consideration on either side than the mutual restraint of the parties, how much restraint of competition is in the public interest, and how much is not.

Like Peckham, Taft thought, "The manifest danger in the administration of justice according to so shifting, vague, and indeterminate a standard would seem to be a strong reason against adopting it."C6 Earlier in the opinion he had said that in cases where restriction of competition is the sole aim of the agreement, "there is no measure of what is necessary to the protection of either party, except the vague and varying opinion of judges as to how much, on principles of political economy, men ought to be allowed to restrain competition." 67

To provide a standard Taft offered, supposedly from the common law, the concept of ancillary restraints. To be lawful an agreement eliminating competition must be ancillary - that is, subordinate and collateral to another legiti-

65. Id. at 283-84. The fact that Taft recognized that his gloss on the common law, considered as description, was partial and inaccurate perhaps provides an additional indication that he was interested in that law not so much for guidance as for a means of preserving the judicial proprieties while lecturing the Supreme Court on the proper means of construing the Sherman Act.

66. Id. at 284 .

67. Id. at 283 . 
mate transaction and necessary to make that transaction effective. This supplied certainty, for the "main purpose of the contract suggests the measure of protection needed, and furnishes a sufficiently uniform standard by which the validity of such restraints may be judicially determined." 68 Taft offered from the common law some suggestions as to restraints considered valid because ancillary to lawful main transactions or purposes:

[A]greements

(1) by the seller of property or business not to compete with the buyer in such a way as to derogate from the value of the property or business sold;

(2) by a retiring partner not to compete with the firm;

(3) by a partner pending the partnership not to do anything to interfere, by competition or otherwise, with the business of the firm;

(4) by the buyer of property not to use the same in competition with the business retained by the seller; and

(5) by an assistant, servant, or agent not to compete with his master or employer after the expiration of his time of service. ${ }^{00}$

Though there is good reason to doubt that all of the listed agreements should be considered legal under the Sherman Act, ${ }^{70}$ Taft's third example - the agreement of partners not to compete with the partnership during its existence is particularly suggestive. L.ike Peckham's list of non-restraints in Joint Traffic, it involves a consolidation or merger. Taft rationalized its validity at common law in policy terms directly applicable to modern antitrust:

... [W] hen two men became partners in a business although their union might reduce competition, this effect was only an incident to the main purpose of a union of their capital, enterprise, and energy to carry on a successful business, and one useful to the community. Restrictions in the articles of partnership upon the business activity of the members, with a view of securing their entire effort in the common enterprise, were, of course, only ancillary to the main end of the union, and were to be encouraged. ${ }^{71}$

Taft very prudently did not limit the possible valid ancillary restraints to the five listed, ${ }^{72}$ and, later in the opinion, he did suggest the application of the ancillarity concept to a vertical arrangement in order to distinguish a case cited by defense counsel from the Addyston fact situation. In the cited case, Chicago, St. L. \& N. O.R. R. v. Pullman Southern Car Co., ${ }^{73}$ the Supreme Court had upheld at common law a contract by which a sleeping-car company, Pullman Southern, had agreed to do all the sleeping-car business of a railroad but exacted the condition that no other sleeping-car company be permitted to

68. Id. at 282.

69. Id. at 281. Paragraphing added.

70. See Section II of this article.

71. $85 \mathrm{Fed}$. at 280 .

72. "It would be stating it too strongly to say that these five classes of covenants in restraint of trade include all of those upheld as valid at common law. . . ." Id. at 282 .

73. 139 U.S. 79 (1891). 
engage in that business on the same line. ${ }^{74}$ Taft justified this vertical arrangement in terms very similar to those he had used in connection with the partnership agreement:

The main purpose of such a contract is to furnish sleeping-car facilities to the public. The railroad company may discharge this duty itself to the public, and allow no one else to do it, or it may hire someone to do it, and, to secure the necessary investment of capital in the discharge of the duty, may secure to the sleeping-car company the same freedom from competition that it would have itself in discharging the duty. The restraint upon itself is properly proportioned to, and is only ancillary to, the main purpose of the contract, which is to secure proper facilities to the public. ${ }^{70}$ Apparently the vertical or horizontal form or appearance of the relationship did not control for Taft the applicability of his formula. Here, as in the partnership illustration, the agreement eliminating competition was viewed as essential to protect a continuing cooperative effort by the parties. ${ }^{70}$

The passage quoted suggests another recurrent theme in antitrust by offering, seemingly as a justification of the exclusive arrangement with the sleeping-car company, the observation that the railroad company could have offered the sleeping-car service itself and allowed no one else to do it. This raises the question - though only to assume the answer - of whether it should always be lawful to accomplish by contract results that may lawfully be attained by ownership. That, of course, is one way of stating the entire problem of price fixing and market division.

Despite their differences in verbalization, Taft's and Peckham's rules of reason are obviously very similar. Taft's non-ancillary restraint is the same thing as Peckham's restraint of trade (or direct restraint) - a cartel agreement. Taft's ancillary restraint was the same thing as Peckham's non-restraint (or indirect restraint) - an agreement eliminating competition ony incidentally to the accomplishment of some other purpose sought by the parties. Taft,

74. It was then customary for the sleeping car company not only to retain title to its cars when in use on the line of a railroad but to furnish the services that were required in the cars.

75. 85 Fed. at 271.

76. Taft also relied upon some less fortunate distinctions of the Pullman Southem case. One was that, in any event, it would be

quite difficult to conceive how competition would be possible upon the same line of railway between sleeping car companies ....

Id. at 287. The car company, however, had thought competition sufficiently possible to require an agreement against it and the law usually does not ask for more proof of the possibility of competition than that. Taft's other distinctions were still worse:

The public interest is satisfactorily secured by the requirement, which may be enforced by any member of the public, to wit, that the charges allowed shall not be unreasonable, and the business is of such a public character that it is entirely subject to legislative regulation in the same interest.

Id. at 287-88. The first of these is decidedly peculiar for a judge who has just been inveighing against the "sea of doubt" which courts embark upon when they attermpt to determine how much restriction of competition is reasonable, and the second suggested rationale would have required a different outcome in the recently decided Trans-dfissouri cace 
like Peckham, said that the form of the agreement would not save its legality if its actual purpose was to suppress competition generally. ${ }^{77}$ It is not clear whether either of them would have upheld an ancillary restraint, to use Taft's terminology, by parties controlling a dominant share of the industry. Such a restraint would have been substantially the same as a merger of a dominant portion of the industry, and, since the Sherman Act for years was uncertain about the legality of monopoly by merger in the absence of abusive or predatory practices, ${ }^{78}$ it is hardly surprising that neither Peckham nor Taft undertook to settle the problem in the context of the cartel cases before them. Taft did say that market power was not essential to illegality in cartel cases.70

The modern law generally holds naked or non-ancillary agreements fixing prices or dividing markets illegal without more, as Taft thought the law should, but his attempt to establish a category of lawful ancillary restraints has had much less success. This aspect of his doctrine has remained undeveloped and its possibilities unexploited. ${ }^{80}$ This is probably because, in the ultimate analysis, Taft, like Peckham, did not himself avoid the "sea of doubt." He was unable adequately to define the main purpose which would justify a supporting elimination of competition beyond the general description that it was "the enjoyment of the legitimate fruits of the contract" or protection from "the dangers of an unjust use of those fruits by the other party." $81 \mathrm{By}$ sweeping the problem under the labels "legitimate" and "unjust" this statement did

77. But, in recent years, even the fact that the contract is one for the salc of property or of business and good will, or for the making of a partnership or a corporation, has not saved it from invalidity if it could be shown that it was only part of a plan to acquire all the property used in a business by one management with a view to establishing a monopoly. Such cases go a step further than those already considercd. In them the actual intent to monopolize must appear. It is not deemed enough that the mere tendency of the provisions of the contract should be to restrain competition. In such cases, the restraint of competition ceases to be ancillary, and becomes the the main purpose of the contract, and the transfer of property and good will, or the partnership agreement, is merely ancillary and subordinate to that purpose.

85 Fed. 271 at 291.

78. Compare, for example, Standard Oil Co. of N.J. v. United States, 221 U.S. 1 (1911), and United States v. American Tobacco Co., 221 U.S. 106 (1911), with United States v. United States Steel Corp., 251 U.S. 417 (1920), and United States v. International Harvester Co., 274 U.S. 693 (1927).

79. 85 Fed. 271 at 291. To be safe, however, Taft found that defendants hatd market power and that the prices they fixed were unreasonable. $I d$. at 291-93. The finding that the prices charged were unreasonable does not cut against his "sea of doubt" argument, for Taft pointed to the letters from the manager of one of the foundries pointing out that it could make what it considered a reasonable profit at prices approximately $\$ 7$ or $\$ 8$ less per ton than those set by the association. Taft might also have pointed to the discrepancy in prices between areas where defendants competed and areas where their acreement was in effect to demonstrate the unreasonableness of the prices in the latter area.

80. The absence of the language of ancillarity from later decisions seems particularly odd since all of the Circuit Court of Appeals judges who participated in the Addyston decision - Harlan and Lurton were the other two - eventually sat on the Supreme Court.

81. . 85 Fed. at 282. 
much to seem to justify the common objection that any restraint can be called ancillary.

Taft's accomplishment in suggesting a structure for the new law was, nevertheless, a considerable one. The main outlines of his solution, though perhaps virtually identical to Peckham's, were offered with much greater elaboration and in clearer language. ${ }^{82}$ His doctrine of ancillary restraints offered the Sherman Act not content but form : a method of preserving socially valuable transactions by defining an exception to an otherwise inflexible prohibition of agreements eliminating competition, and a formula for confining the exception to the area of its reason for existence.

\section{Chief Justice White's 1911 Rule of Reason}

Chief Justice White's opinions in the 1911 Standard Oil and Ancrican Tobacco cases must certainly rank among the most artful in antitrust. They were, of course, merger and monopolization cases, but White took them as occasions to expound the structure of the law generally. Their main fault and it is a grievous one - is that they were capable of being, and were, so thoroughly misunderstood that many people believed the Supreme Court had changed the substance of the Sherman Act.83 This was due not only to Harlan's violent and mistaken dissent but also to the notorious opacity of White's prose, as well as to his use of the phrase "rule of reason" to signify a set of criteria wholly opposed to those he had indicated by the same term in his 1897 TransMissouri dissent.

Yet the need for a restatement of the law must have seemed compelling. Peckham's opinions had been largely misunderstood, causing widespread apprehension in the business community. After that, the famous debate between Harlan and Holmes in the 1904 Northern Secturities case must have suggested that the law was either unintelligible or unworkable, or both.84 The major

82. It is difficult to guess how much Peckham and Taft may have influcnced cach other. Addyston came after Trans-Missouri but the latter opinion by itself may have given little guidance as to Peckham's complete solution. It seems unlikely, therefore, that Pecl:ham influenced Taft On the other hand, there is no indication of influence running the other direction. After Addyston Peckham did not deviate from the position he had taken in Trans-Missouri; he continued to insist that the statute precluded any test of reasonableness and sought to achieve flexibility through definition of the phrase "restraint of trade" It seems likely that Peckham and Taft worked out their formulae independently, influenced less by one another than by the nature of the phenomena with which the lav they were making had to deal.

83. The sharp and widespread dissatisfaction with what was erroneously conceived to be the Court's abandonment of Peckham's "literal" reading of the Sherman Act and its supposed assumption of the legislative power to determine how much competition is in the public interest is well known. See, for example, the authorities cited in Harroner, ArimTRUST IN Perspective (1957) Ch. I, notes 5, 6, 8, and 9, particularly Afontague, AntiTrust Laws and the Federal Trade Commission, 1914-1927, 27 CoLus. L. REv. 650, 651-54 (1927). Montague, however, expresses a minority view on the literary quality of the 1911 opinions: "the highest emotion they stir is a mild thrill to the sonority of Chicf Justice White's prose style. Great music is like that." Id. at 651.

84. See text accompanying notes 104-12 and 117-30 infra. 
virtues of the Standard Oil and American Tobacco opinions, moreover, are numerous. The business community was reassured by the introduction of the phrase "rule of reason" that not every consolidation was unlawful; the Act was related in a plausible manner to the common law without being controlled by it; a dynamic principle was built into the rule of reason so that the law could change as economic understanding progressed; and, finally, the substance of the law as worked out by Peckham was articulated in new form but brought forward substantially without change.

White began by saying that the terms of the Sherman Act - restraint of trade, attempt to monopolize, and monopolization - "at least in their rudimentary meaning, took their origin in the common law, and were also familiar in the law of this country prior to and at the time of the adoption of the act in question." ${ }^{\text {" } 5 ~} \mathrm{He}$ therefore proposed to examine not the complicated body of precedent built up at common law but "the elementary and indisputable conceptions of both the English and American law on the subject prior to the passage of the Anti-trust act."86 In a passage crucial to his reasoning White said :

The evils which led to the public outcry against monopolies and to the final denial of the power to make them may be thus summarily stated: 1. The power which the monopoly gave to the one who enjoyed it to fix the price and thereby injure the public; 2 . The power which it engendered of enabling a limitation on production; and 3 . The danger of deterioration in quality of the monopolized article which it was deemed was the inevitable resultant of the monopolistic control over its production and sale. ${ }^{87}$

Gradually, according to White, in this country as in England the name of "monopoly" came to be associated with any acts which produced the harmful results of Crown grants of monopolies. There thus grew up "fear as to the evil consequences which might arise from the acts of individuals producing or tending to produce the consequences of monopoly." $88 \mathrm{By}$ focusing on consequences rather than form, White introduced into the common law an engine of change and growth: "... [A]s modern conditions arose the trend of legislation and judicial decision came more and more to adopt the recognized restrictions to new manifestations of conduct or of dealing which it was thought justified the inference of intent to do the wrongs which it had been the purpose to prevent from the beginning." 89 The guiding principle was thus the prohibition of "all contracts or acts which were unreasonably restrictive of

85. 221 U.S. 1, 50-51.

86. Id. at 51 .

87. Id. at 52. The common law was concerned with monopoly only when it resulted from a grant by the Crown. The courts' objection to it seems to have been primarily an aspect of the struggle between Crown and Parliament. Nevertheless, pro-consumer arguments were made in the course of disputes over Crown-granted monopolies and these gave some support to White's remarks. See Darcy v. Allen, F. Moore 673, 11 Coke 84.

88. 221 U.S. at 57.

89. Id. at 57-58. 
competitive conditions, either from the nature or character of the contract or act or where the surrounding circumstances were such as to justify the conclusion" that they had not the "legitimate purpose of reasonably forwarding personal interest and developing trade" but rather had been intended "to bring about the evils, such as enhancement of prices, which were considered to be against public policy."90

White's next task was to equate this highly colored version of the common law's "elementary and indisputable conceptions" with the Sherman Act. He bridged the gap by employing a distinction he had already made between restraints of trade in the "subjective sense" and those in the "broad" or "generic sense." The former were voluntary restraints a person put upon his freedom to pursue his calling. Restraints in the "broad sense," according to White, were those "contracts or acts which it was considered had a monopolistic tendency, especially those which were thought to unduly diminish competition and hence to enhance prices - in other words to monopolize . . . .n1 White contended that

the context manifests that the statute was drawn in the light of the existing practical conception of the law of restraint of trade [as contrasted with the actual body of precedent], because it groups as within that class, not only contracts which were in restraint of trade in the subjective sense, but all contracts or acts which theoretically were attempts to monopolize, yet which in practice had come to be considered as in restraint of trade in a broad sense. ${ }^{22}$

The Act's reference to restraints in the broad or generic sense lay, presumably, in section 1's prohibition in addition to "contracts" of "Every ... combination in the form of trust or otherwise, or conspiracy, in restraint of trade or commerce .... .93 The Sherman Act thus incorporated the economic standards the prevention or elimination of the power to fix prices, of the power to restrict output, and of the danger of deterioration in product quality - which White claimed were the elementary conceptions of the common law. Since the statute prohibited "classes of acts" which were "broad enough to embrace every conceivable contract or combination which could be made concerning trade or commerce" the courts must exercise judgment according to a "standard of reason" - it became the "rule of reason" a few paragraphs later — to determine whether the statute was violated.94

Far from encompassing the destruction of the Sherman Act or giving to courts the unlimited power to say which trusts or cartels were "good" and which "bad," as so many critics immediately claimed," White had phrased

90. Id. at 58.

91. Id. at 57.

92. Id. at 59 .

93. Id. at 49.

94. Id. at 60 .

95. See note 83 supra. The passage of the Clayton Act and the Federal Trade Commission Act in 1914 owed much to the common misunderstanding of White's interpretation of the statute. See Henderson, The Federal Trade Cosnrsssiosi 6-20 (1924); and 
a rule of reason keyed to the avoidance of the consequences of monopoly and had placed upon the courts the duty of performing economic analysis to determine in which acts and agreements the evils of monopoly were present. In the area of loose arrangements he clearly contemplated a test much like Peckham's, or Taft's, and provided for a category of agreements illegal per se. Thus, restating the rule of reason in American Tobacco, White said "the words 'restraint of trade' ... only embraced acts or contracts or agreements or combinations . . . which, either because of their inherent nature or effect or because of the evident purpose of the acts, etc., injuriously restrained trade. . . ." If this is read as a three-part test, ${ }^{97}$ White's rule of reason held an agreement unlawful if its inherent nature, or its effect, or its purpose was to produce the evils of monopoly. Since White now apparently accepted Trans-Missouri and Joint Traffic as correctly decided against defendants without trial, ${ }^{08}$ the "inherent nature" test was probably a per se rule holding cartel agreements, or, if you like, non-ancillary restraints, unlawful without more. If the agreement was not on its face one within this per se category, the rule of reason required examination of the purpose of the parties or the effects actually produced to determine whether the evils of monopoly were intended or achieved. If the word "inherent" in White's sentence modifies "effect," as seems likely, it may be that the test contemplated not an examination of actual effects but an inference of the effect from some other fact, probably from the market size or power of the party or parties. If so, the test may state that an agreement or behavior is illegal if either its inherent nature (the per se concept), its inherent effect (shown by market power), or its purpose is to achieve the evils specified by White as attributable to monopoly.

Also built into White's doctrine was concern for the efficiencies that might be created by contract or combination. He was careful to point out that "the statute did not forbid or restrain the power to make normal and usual contracts to further trade by resorting to all normal methods, whether by agreement or otherwise ...." Certainly White indicated that the mere elimination of competition by agreement was not enough to confer illegality, and he appears to have been concerned not to destroy combinations that created efficiency. This was true even in his application of the law to the Standard Oil and American Tobacco trusts. There he seemed to say that not even mergers and stock transfers creating firms of such enormous market size were necessarily

Cushran, The Independent Regulatory Commissions 178-87 (1941). Ironically, White's concern that the antitrust law be suitably flexible led, through a misreading of the tests he suggested, to the enactment of statutes which have had the result of introducing harsh and rigid rules against a variety of business practices which he apparently regarded as normal methods of trade.

96. 221 U.S. 106, 179.

97. The language can also be read as a two-part test by understanding inherent nature and effect to mean the same thing.

98. 221 U.S. 1, 64-68.

99. 221 U.S. $106,179$. 
illegal. Rather, he treated even the deliberate gathering of control over the petroleum industry in the hands of Standard of New Jersey as creating, "in the absence of countervailing circumstances," a "prima facie presumption" of intent to maintain dominance over the industry, not only by "normal methods of industrial development, but by new means of combination which were resorted to in order that greater power might be added than would otherwise have arisen had normal methods been followed, the whole with the purpose of excluding others from the trade . . "100 This "prima facie presumption" was made conclusive by observing that such methods had actually been used to exclude others from the industry. ${ }^{101}$ The opinion is thus preoccupied with abuses, predatory practices, or unnatural methods of gaining and maintaining market position. The function of abuses, apparently, is to reassure the Court that the attainment and maintenance of size was not due to efficiency. ${ }^{102}$ It is impossible from this to do more than conclude that concern for efficiency played a leading role in White's rule of reason, for the case did not present the opportunity to demonstrate the role of that concern where loose arrangements not accompanied by predatory practices were involved.

White himself pointed out the similarity or even identity of his rule to Peckham's. ${ }^{103}$ Though this is often taken as an example of the common judicial tactic of insisting that the law is unchanged while changing it, it seems likely here that White was both sincere and accurate. No case up to that time, not even the Northern Securifies decision, had held that all eliminations of competition were per se unlawful. White's acceptance of Trans-Mfissouri and Joint Traffic and his own three-part test result in a rule of reason largely, if not completely, convertible either to Peckham's test of direct and indirect restraints or Taft's test of ancillary and non-ancillary restraints. It should be stressed that White's test was phrased wholly in economic terms, giving no evidence of concern for possibly competing values. A corollary of this value choice is that the law should develop according to the progress of economic thought. The law is, therefore, neither made inflexible by controlling precedent nor required to change only through abrupt shifts of basic doctrine. Thus a court could alter the law without repudiating the theory underlying prior decisions by explaining that those decisions had misconceived the economic effect of particular agreements or practices. This characteristic is, of course, inherent in Peckham's and Taft's statements of the rule of reason, as it is in any law governed by economic analysis. Only White, however, made the mechanism of change explicit by incorporating his version of the common law - with its principle of focusing always upon the consequences of monopoly for consumers - into the Sherman Act.

100. 221 U.S. $1,75$.

101. Id. at 75-77.

102. See also the treatment of this theme in American Tobacco, 221 U.S. 105, 181-83.

103. 221 U.S. $1,66$. 


\section{Justice Harlan's Obscurities}

Justice Harlan is often taken to have been an enemy of the rule of reason and to have insisted on an absolute rule of per se illegality for all agreements or integrations that eliminated competition. This view rests primarily tpon his opinion for the Court in the 1904 Northern Securities decision ${ }^{104}$ and his indignant dissents to the later Standard Oil and American Tobacco opinions. Yet it seems clear, or as clear as such questions usually admit of being, that this is a misreading of Harlan. Just as Harlan's dissents in Standard Oil and American Tobacco misled many persons into thinking that White had there adopted his old reasonable-price criterion, so Holmes' dissent in Northcrn Securities has misled many to believe that Harlan had there adopted a rigid per se stance. The confusion in Northern Securities may have arisen because Harlan and Holmes perceived the economic phenomenon before the Court differently and were talking past each other. Holmes, failing to realize that Hurlan was enunciating the law applicable to a wholly different sort of economic arrangement, proceeded to show that Harlan's law made no sense applied to Holmes' view of the facts.

The case concerned the elimination of competition between the Great North ern Railway Company and the Northern Pacific Railway Company which operated, according to Harlan's opinion, "parallel and competing lines across the continent through the northern tier of states between the Great Lakes and the Pacific. ..."105 James J. Hill, and associate stockholders of Great Northern, and J. Pierpont Morgan, and associate stockholders of the Northern Pacific, formed the Northern Securities Company, with a capital stock of $\$ 400,000,000$, which then exchanged its stock for capital stock of the two railroad companies and thus acquired control of both.

Harlan wrote for four Justices holding the fusion of ownership of the two competing railroads through a holding company violative of sections 1 and 2 of the Sherman Act; Holmes wrote for four dissenters; and Brewer's concurrence in a separate opinion made a majority for Harlan's outcome. Furlan's opinion never rose much above heavy insistence upon such propositions as "every combination or conspiracy which would extinguish competition between otherwise competing railroads engaged in interstate trade or commerce, and which would in that way restrain such trade or commerce, is made illegal by the act." 106

Holmes' dissent pointed out that a fusion or consolidation was involved and that a law which forbade all elimination of competition by such means would not merely destroy such normal business entities as partnerships but would require the atomization of society.

104. Northern Sec. Co. v. United States, 193 U.S. 197 (1904).

105. Id. at 320 .

106. Id. at 331 . Italics in the original. 
Never notably adept at doctrinal disputation, ${ }^{107}$ Harlan did not clearly articulate an answer to Holmes' charge. He seems, however, to have analyzed the case as not involving a consolidation or fusion, such as a partnership or a merger, but as presenting, essentially, only a cartel. Under that view the case required no more than the broad slogans he extracted from such prior decisions as Trans-Missouri and Joint Traffic. This would explain also Harlan's failure to discuss issues such as market dominance or predatory practices that might have been relevant to a merger case. Credibility is lent to this reading by several other aspects of Harlan's opinion. The "combination" he referred to as illegal was not the holding company itself but the antecedent agreement and cooperation of the stockholders of the two roads. He viewed this combination, led by Hill and Morgan, as organizing and using the holding company merely as a device to attain improper ends. ${ }^{108}$ Moreover, Harlan stressed the use of the holding company device, italicizing the word "holding" repeatedly, apparently to emphasize that there is something peculiar about a company that merely holds. And apparently what was peculiar in Harlan's eyes was that there was no real fusion. He stressed the lack of real fusion when he

107. Harlan's ineptitude in dogmatic analysis in Northern Sccuritics and in the Stondard Oil and American Tobacco cases gives added point to a remark Holmes made about him in another connection:

... [T] [Tat sage, although a man of real power, did not shine either in analysis or generalization and I never troubled myself much when he shied. I used to say that he had a powerful vise the jaws of which couldn't be got nearer than two inches to each other.

2 HozMres-Poliock Letters, 7-8 (Howe ed. 1941).

108. ... [U]nder the leadership of the defendants Hill and MForgan the stockholders of the Great Northem and Northern Pacific Railway corporations ... combined and conceived the scheme of organizing a corporation ... . which should hold the shares of the stock of the constituent companies...

193 U.S. 197, 326 (Italics in original). He refers to the holding company as carrying out the purpose of the "original combination." Id. at 326-27. And

[W] hat the Government particularly complains of, indeed, all that it complains of here, is the existence of a combination among the stockholders of competing railroad companies which in violation of the act of Congress restrains interstate and international commerce through the agency of a common corporate trustee designated to act for both companies in represssing free competition between them.

Id. at 335. This may illuminate Harlan's pronouncement elsewhere that

The mere existence of such a combination and the power acquired by the holding company as its trustee, constitute a menace to, and a restraint upon, that freedom of commerce which Congress intended to recognize and protect, and which the public is entitled to have protected.

Id. at 327 . This may be and sometimes is read as a statement that a merger involving market power is illegal without more under section 1 of the Sherman Act, or, if the "power" of the holding company be taken simply as the ability to eliminate competition between formerly competing units, as a statement that a merger eliminating any competition is illegal without regard either to intent or market power. It seems more plausible, in view of Harlan's usage elsewhere in the opinion, to read "combination" here as referring not to Northern Securities itself but to the prior cooperation between Hill and Morgan and their associated stockholders and thus to interpret the remark as a statement of the per se illegality not of mergers but of cartels. 
said that the holding company was "to manage, or cause to be managed, both lines of railroad as if held in one ownership."100 Harlan also emphasized Morgan's testimony to refute the theory that a mere investment by Northern Securities was involved, and this further demonstrated his view of the transaction. Asked why the stocks of both railroads were placed in one holding company Morgan had answered that the "holding company was simply a question of custodian because it had no other alliances." Of this Harlan said, "That disclosed the actual nature of the transaction, which was only to organize the Northern Securities Company as a holding company, in whose hands, not as a real purchaser or absolute owner, but simply as custodian were to be placed the stocks of the constituent companies - such custodian to represent the combination formed between the shareholders of the constituent companies, the direct and necessary effect of such combination being, as already indicated, to restrain and monopolize interstate commerce by suppressing, or (to use the words of this court in United States v. Joint Traffic Assn.) 'smothering' competition between the lines of two railway carriers."110 Everything about this

109. Id. at 326. Italics added. Italics removed from last three words of quotation. Defendants' briefs also stressed the lack of any real fusion of the railroad companies, pointing out that they retained separate managements and boards of directors. Though defendants intended thus to show that competition between the roads would continue, it may well have had the effect of convincing some of the justices that this was not a fusion of productive activities like that in a partnership or a merger but merely a profit pooling plan. The primary reason defendants gave for the formation of Northern Securities was the desire to put the controlling interest of the Northern Pacific out of reach of the owncrs of Union Pacific or other "raiders". Since the active parties also held Great Northern stock, it was decided, according to defendants, to have Northern Securities offer to ptrchase Great Northern stock as well. See, for example, Brief for Northern Securities Company, filed by John G. Johnson, p. 10. J. P. Morgan testified, however, that the purpose of putting the stock of both railroad companies in one holding company was simply to form a company "with capital large enough that nobody ever could buy it." Quoted from record in Brief for the United States, p. 37.

110. 193 U.S. at 354. Harlan's use of this quotation from Morgan's testimony seens questionable since the line Harlan quoted was followed very shortly by the further explanation that the purpose of making the Northern Securities Company a "custodian" was to form a holding company whose capital was so large as to make it impervious to raids. This testimony may not have been believable, but it hardly seems to support Flarlan's attempt to convict Morgan of a purpose to suppress competition out of his own mouth. Morgan's testimony could have been used to show that the joint ownership of the two roads eliminated competition without any of the compensating efficiencies that make mergers, unlike cartels, susceptible of justification.

The fact that neither side argued the question of efficiencies and that neither side attempted a distinction between cartels, on the one hand, and mergers and partnerships, on the other, indicates that the law was still groping for its basic distinctions. In his oral argument, counsel for defendants put the questions which seemed so troublesome to Holmes. See text accompanying notes 123, 124 infra. Oral Argument of George B. Young, for the Appellants, in reply to the Attorney-General, Dec. 15, 1903, pp. 6-7. These come down to the question of whether the government's argument that the suppression of competition by contract or combination was per se illegal would not preclude every merger of competitors, every partnership between competitors, and every purchase by one competitor of another's business. The government seems to have answered Mr. Young by distinguishing this case 
passage - the stress on the fact that the holding company was to be a custodian and not a real purchaser or owner, the identification of the combinatiou as being between the shareholders and not between the railroads, the references to Joint Traffic - indicates that Harlan considered he was dealing with a cartel and not a merger.

This interpretation of the opinion is not only more consistent with the text than the usual reading given it, but makes sense of a position which otherwise seems exposed as inane by Holmes' dissent. ${ }^{111}$ It seems clear, then, that Harlan in this case was well within the proper limits of the per se rules established by Peckham and Taft. He saw the holding company as no more than a profitpooling device and therefore the exact equivalent of a price-fixing agreement. The fact that Peckham concurred in Holmes' dissent probably indicates not that Harlan had changed the law nor that Peckham had reneged on the rationale of his earlier opinions but only that the latter agreed with Holmes that a fusion or merger was involved. ${ }^{112}$

from the ordinary partnership or merger on the grounds of intent. Here suppression of competition was the purpose, while in the other cases it would be "only ancillary and collateral to the main object." Brief for the United States, p. 72. But it may also have been relevant from the government's point of view that the fusion created power to raise prices or suppress competition. Id. at 76-78. The power seems more to have been assumed than argued, except that the government framed many of its legal propositions specifially in terms of railroads and the fact that defendants were railroads may have been thought to create power. See, for example, Oral Argument of the Attorney-General of the United States, pp. 28-29. This may suggest that power was thought an essential element in the illegality of cartels and also, as Brewer's concurrence suggested, that railroads occupied a special category. See note 112 infra.

111. It also demonstrates that Northerri Securities should not be viewed as a merger precedent, though commonly used as such. Justice Douglas, for example, recently cmployed the case as a crucial precedent in a merger case, United States v. First Nat'l Bank \& Trust Co. of Lexington, 376 U.S. 665, 670 (1964).

112. Justice Brewer, concurring, seemed to agree that Northern Securities was essentially a cartel case, 193 U.S. at 362, but he thought a test of reasonableness had to be introduced to save "those minor contracts in partial restraint of trade" which the common law upheld and to allow for the "inalienable rights" of individual citizens to invest in the stock of corporations although that might result in the destruction of competition. Id. at 361. The first of these objections to the law announced in prior cases seems to involve a misunderstanding of their rationale, but the second, if taken seriously, would hare required a modification of the rule as phrased by Peckham. Brewer did not fully articulate his standard of reasonableness, but, it seems, with the exception noted, not to have differed greatly from Peckham's, utilizing a test of whether the purpose and effect of a transaction was the general suppression of competition. Perhaps his test required market powier, for he stated:

It must also be remembered that under present conditions a single railrosd is, if not a legal, largely a practical, monopoly, and the arrangement by which the control of these two competing roads was merged in a single corporation broadens and extends such monopoly. I cannot look upon it as other than an unreasonable combination in restraint of interstate commerce ....

Id: at 363 . This analysis, though seemingly made in connection with a cartel case, was later applied in railroad merger cases, apparently to supply the requisite market power, and thus formed the basis for the observation that the Sherman Act treated railroad mergers 
Harlan's dissents in Standard Oil and American Tobacco ${ }^{113}$ protested against what he erroneously believed to be a return to an undefined standard of reasonableness rejected by the Court in Trans-Missouri and Joint Traffic. Thus, Harlan, though confused concerning the Court's doctrine, actually was in substantial agreement with it.

\section{Justice Hughes and Vertical Price Fixing}

The early cases made no distinction between horizontal and vertical price fixing. In 1911, shortly before the Standard Oil and American Tobacco cases, the Supreme Court in the Dr. Miles case, ${ }^{114}$ reviewing the dismissal of a complaint on demurrer, held illegal a resale price maintenance program maintained by a manufacturer of proprietary medicines through an enormous network of contracts with wholesalers and retailers. To the manufacturer's assertion that a standard retail price was important to it and that confusion and damage had resulted from sales at less than the prices fixed, Justice Hughes for the Court replied that the advantages of the scheme went to the dealers rather than the manufacturer. But then Hughes faced the claim directly and rejected it:

If there be an advantage to the manufacturer in the maintenance of fixed retail prices, the question remains whether it is one which he is entitled to secure by agreements restricting the freedom of trade on the part of dealers who own what they sell. As to this, complainant can fare no better with its plan of identical contracts than could the dealers themselves if they formed a combination and endeavored to establish the same restrictions, and thus to achieve the same result, by agreement with each other. If the immediate advantage they would thus obtain would not be sufficient to sustain a direct agreement, the asserted ulterior benefit to the complainant cannot be regarded as sufficient to support its system.116

Aside from its equation of horizontal and vertical price fixing, this passage is interesting because it failed to ask whether the manufacturer's interest in eliminating price competition between its distributors could be related to a

more severely than other mergers. See Levi, The Antitrust Lauts and Monopoly, $14 \mathrm{U}$. CHI. L. REv. 153, 157 (1947).

Rather surprisingly, this old "railroad category" of Sherman Act merger cases has recently been resurrected and applied by a Supreme Court majority to a non-railroad merger. To say in the Lexington Bank case, supra note 111, as the Court did, that it is governed by Northern Secturities is not merely to apply a cartel precedent in the merger area, but to suggest the application of railroad merger precedent, regardless of the uniqueness of that category, to all combinations.

113. Standard Oil Co. of New Jersey v. United States, 221 U.S. 1, 82-106 (1911); United States v. American Tobacco Co., 221 U.S. 106, 189-93 (1911).

114. Dr. Miles Medical Co. v. John D. Park \& Sons Co., 220 U.S. 373 (1911).

115. Id. at 408-09. The proximity of this decision, which rests by analogy on the per se illegality of horizontal price fixing, to the Standard Oil and American Tobacco decisions is additional evidence that those cases did not overturn the rule of Trans-Missonti and Joint Traffic. Standard Oil and American Tobacco were both argued and reargucd prior to the decision of Dr. Miles. They were handed down in April and Dr. Miles came down in May. It is far-fetched to imagine that the Court was abandoning the rule of strict illegality for cartel arrangements in the Standard Oil and American Tobacco cases at the same time that it was making that rule the pivotal point of its Dr. Miles rationale. 
valid main purpose capable of legitimating the contracts. Taft had suggested in Addyston that a vertical arrangement might be validated on that ground. In Dr. Miles Hughes ignored or rejected that lead and it was not until over sixty years had passed that Douglas in White Motor very tentatively advanced the same idea, though, rather inconsistently, being careful to limit even the possibility of legality to market divisions and stressing the continuing vitality of Dr. Miles' rule against resale price maintenance. 110

The Establishment of Deviant Themes in the Rule of Reason

The principal architects of theoretical structures that differ significantly from the dominant Peckham-Taft-White version are Justices Holmes and Brandeis. Brandeis' philosophy of the Act is far and away the more important and influential today. Holmes' reading of the statute, which was curiously mechanical and internally inconsistent, has had no appreciable impact upon the law's development.

\section{The Lawe According to Justice Holmes}

Holmes attempted his one general structuring of the Sherman Act in his 1904 Northern Securities dissent. It seems fair to say that the structure he suggested was keyed to no particularly intelligible policy and that the oblivion into which it lapsed was well earned. It is also necessary to say, however, that Holmes put basic questions concerning the Act and its policy which remain provocative today.

The crux of Holmes' position was that the statute must be interpreted in strict accordance with the common law whose terms it employed and without reference to any supposed policy of preserving competition. "The act," he insisted, "says nothing about competition."117 If it did say anything about competition, he suggested, it was that a little bit went a long way. As shown by the statute's use of the words "in the form of trust or otherwise," which was suggested by the then popular trust device for putting together industries such as oil, the statute was aimed not at the elimination of competition by unions of competitors, Holmes said, but at "the sinister power exercised or supposed to be exercised by the combination in keeping rivals out of the business and ruining those who already were in. It was the ferocious extreme of competition with others, not the cessation of competition among the partners, that was the evil feared."118 Claiming to stick to the actual text of the statute, Holmes argued:

The words hit two classes of cases, and only two - contracts in restraint of trade and combinations or conspiracies in restraint of trade. ... Contracts in restraint of trade are dealt with and defined by the common law. They are contracts with a stranger to the contractor's business (although, in some cases, carrying on a similar one), which wholly or partially restrict the freedom of the contractor in carrying on that business as other-

116. White Motor Co. v. United States, 372 U.S. 253, 260 (1963).

117. Northern Sec. Co. v. United States, 193 U.S. at 403.

118. Id. at 405. 
wise he would. . . . Of course, this objection did not apply to partnerships or other forms, if there were any, of substituting a community of interest where there had been competition. ... . Combinations or conspiracies in restraint of trade, on the other hand, were combinations to keep strangers to the agreement out of the business. The objection to them was not an objection to their effect upon the parties making the contract, the members of the combination or firm, but an objection to their intended effect upon strangers to the firm and their supposed consequent effect upon the public at large. In other words, they were regarded as contrary to public policy because they monopolized, or attempted to monopolize, some portion of the trade or commerce of the realm.110

This passage contains surprising inconsistencies. If he had succeeded in ridding the Act of competition as a standard, Holmes would also have destroyed the rule of reason Peckham had created. Holmes' reading, then, would have outlawed all the so-called ancillary or collateral restraints known to the common law which did not involve the creation of a community of interest. Perhaps this result could have been avoided by saying that a contract not to compete with the purchaser of one's business was not a contract with a stranger to the business and hence not one in restraint of trade. That would have made Holmes' interpretation workable but it would also have destroyed the sole merit he claimed for it - fidelity to the common law meaning of the words used.

A more fundamental objection is that Holmes' reading came dangerously close to leaving the law bereft of reason for existence. If competition was not the guiding policy, it would be difficult to understand the Trans-Missouri and Joint Traffic decisions which Holmes said he accepted "absolutely, not only as binding upon me, but as decisions which I have no desire to criticize or abridge."120 The policy behind those decisions can hardly have been, as a common law rationale would suggest, to protect the railroads from improvident bargains. The cases either rested on a policy of preserving competition or must be taken as wholly incoherent.

Holmes' inability to keep competition out of an Act which, he insisted, said nothing about it was underscored by his statement that the aggressions of combinations were feared because of their "intended effect upon strangers" and "their supposed consequent effect upon the public at large." The adverse effect upon the public can hardly have been anything other than the ultimate loss of competition.

Holmes' construction of the Sherman Act was thus not merely at odds with the common law, which he claimed was controlling, but, on its own premises, was internally inconsistent and geared to no discernible rational policy consideration. The only way in which Holmes' reading of the Act can be made sensible, and, indeed, begin to shed light on the fundamental problems of this area of the law, is to put back into it the economic ideas associated with the policy of competition which Holmes claimed to exclude. Thus, in terms of

119. Id. at 404.

120. Id. at 405 . 
results rather than supporting generalizations, it is possible to read Holmes as follows: The Sherman Act condemns all cartel agreements between persons whose businesses remain otherwise independent; it condemns all excessive competition by combinations or individuals whose purpose is the exclusion of others from the industry; it permits the elimination of all competition by the "substituting [of] a community of interest where there had been competition." The concern for the elimination of competition in the first two branches of this restatement may seem to contrast oddly with the seeming indifference to it in the last. Holmes' surface answer - that that's the way the common law is and we are only concerned with the reading of words defined by the common law - is clearly nonsensical, but behind it may have lain his concern that if Northern Securities Company, which he saw as a fusion or merger, were struck down as a combination in restraint of trade, logical consistency would "require all existing competitions to be kept on foot, and, on the principle of the Trans-Missouri Freight Association's case, invalidate the continuance of old contracts by which former competitors united in the past."121 The weakness of the structure Holmes would have imposed on the statute is that it would have allowed unlimited elimination of competition by merger. Cartelists could easily have evaded the rule of Trans-Missouri by utilizing purely formal fusions of their firms since Holmes had argued that not even a proved intent to suppress competition would defeat a holding company's legality. Nevertheless, he had hold of a crucial economic distinction - that between cartels and mergers - when he said that "To suppress competition in that way [by a contract with a stranger to one's business] is one thing; to suppress it by fusion is another."122

He picked up this theme again: "To see whether I am wrong, the illustrations put in the argument are of use. If $I$ am, then a partnership between two stage drivers who had been competitors in driving across a state line, or two merchants once engaged in rival commerce among the States whether made after or before the act, if now continued, is a crime. For, again I repeat, if the restraint on the freedom of the members of a combination caused by their entering into a partnership is a restraint of trade, every such combination, as well the small as the great, is within the act."123 $\mathrm{He}$ said that this interpretation "would make eternal the bellum omminn contra ommes and disintegrate society so far as it could into individual atoms."12s

Holmes was right of course in recognizing that any absolute per se rule against the elimination of competition was impossible, inconsistent even with the most primitive forms of society. The difficulty he saw could have been solved by giving heed to the full implications of Peckham's definition of "restraint of trade" as the suppression of competition in the general market. Cartels, which make no sense unless effective to smother competition generally,

121. Id. at 410 .

122. Ibid.

123. Id. at $410-11$.

124. Id. at 411 . 
are thus rendered automatically illegal, while mergers, which very often do make sense to the parties without any adverse general effect upon competition, would be outlawed only if the parties had such large market shares that general competition was stifled. This distinction would have enabled Holmes to hold the combination in Northern Securities illegal without adopting a rulo requiring the atomization of society. But Holmes thought the statute unable to distinguish between combinations of different size because he thought of size in the absolute sense. ${ }^{125}$ The use of a test keyed to competition and its preservation would have enabled him to distinguish between combinations of different sizes relative to their markets. ${ }^{126}$ First and last, Holmes' construction of the statute was stultified by his efforts to keep competition out of it.

Holmes also queried the application of the statute to mergers on one additional ground: Since a single corporation could lawfully have constructed the lines of both railroads, how could it be unlawful for a single corporation to purchase them both after they were built ${ }^{127}$ This shotild be compared with the question Taft had raised: If a railroad corporation could lawfully furnish sleeping-car service itself, and thus exclude all competitive furnishers of that service, how could it be unlawful for it to hire another to provide the service and exclude would-be competitors by contract?2128 These are basic questions with which the rule of reason is still struggling. ${ }^{120}$

Holmes' contribution to the rule of reason, then, was quite limited. To his credit, he effectively destroyed the notion that any absolute per se rule aganst all arrangements that eliminate competition is even a theoretical possibility. His attempted positive contributions, however, were largely invalidated because he approached antitrust not only without an adequate understanding of basic economic concepts, ${ }^{130}$ but with a denial even of the relevance of competition. The fact that he proved unable to keep the concept of competition, and hence economic reasoning, out of his analyses made them somewhat inconsistent but also gave them whatever value and provocativeness they possessed.

125. Id. at 407-08.

126. This, of course, is what Peckham's formula as to restraint of trade allowed. Peckham's agreement with Holmes may have been due to the fact that he saw the case as involving a merger and thought that market size had not sufficiently been shown, or perhaps he was not ready to apply his formula to mergers at all.

127. Id. at 407.

128. See text following note 72 stipra.

129. See, for example, Justice Brennan's concurring opinion in White Motors v. United States, 372 U.S. 253, 264 (1963), discussed in Section II of this article.

130. Thus, in his Dr. Miles dissent, speaking not just of resale price maintenance but, apparently, of problems of competition and monopoly generally, Holmes said: "I think that we greatly exaggerate the value and importance to the public of competition in the production or distribution of an article (here it is only distribution) as fixing a fair price." 220 U.S. 373, 412 (1911). He thought that interproduct or inter-industry rivalry fixed the fair price. Ibid. Holmes thus demonstrated that he did not understand the role of competition, including competition between producers and between distributors of the samo product, in allocating resources so as to maximize consumer satisfaction. 


\section{The Law According to Justice Brandeis}

Brandeis' rule of reason, though also well outside the main tradition of the law has, unlike Holmes', not proven barren. The difference springs from two factors. A strong underlying policy orientation of Brandeis' rule seems to have been sympathy for small, perhaps inefficient, traders who might go under in fully competitive markets. His rule thus spoke for the tempering of competition by private agreement. This, of course, is an enduring strand in antitrust policy, reflecting there a strong anticompetitive element of our national social policy. But the staying power of Brandeis' rule probably owes as much to its very lack of that conceptual clarity which characterized Holmes' rule. Its less respectable, because unadmitted, anticompetitive aspects were thus often diffcult to isolate and identify. This very element of blurriness, moreover, made Brandeis' version of the law convenient for judges working within the main tradition whose own doctrine lacked sufficient distinctions to validate the occasional agreement not to compete which seemed legitimate for reasons they found difficult to articulate. Brandeis' phrasing of doctrine thus sometimes served to give the Peckham-Taft-White rule of reason the flexibility which it required but lacked the economic framework to achieve.

Brandeis' opinion for the Court in the 1918 Chicago Board of Trade case ${ }^{131}$ is at once illustrative of his ideas and an important, though ambiguous, antitrust precedent. The case arose on the government's suit to enjoin the Board of Trade's enforcement of a rule fixing the prices at which its members could make certain sales and purchases. The Board provided an exchange for grain trading for its approximately 1600 members, who included brokers, commission merchants, dealers, millers, maltsters, makers of corn products, and elevator owners. Transactions at Board sessions, on bids and sales publicly made, were between members only, but members traded on behalf of others as well as themselves and were also permitted to trade privately with each other and with non-members, though not on premises occupied by the Board. The regulation attacked by the government was the price-fixing portion of the Board's "call" rule. The "call" was a special session of the Board held immediately after the close of each day's regular session. The regular session was taken up with spot sales and future sales (respectively, sales of grain already in Chicago in railroad cars or elevators for immediate delivery, and agreements for delivery later in the current or in some future month). The "call" was occupied with sales "to arrive" (agreements to deliver on arrival grain which was already in transit to Chicago or was to be shipped there within a specified time). Purchases of grain "to arrive" were made not only at the "call" from members who offered it on behalf of others but also were made directly from country dealers and farmers, sometimes by telephone or telegraphed bids, but most often by sending out offers to purchase to hundreds of country dealers by the afternoon mail, subject to acceptance before 9:30 a.m. on the next business day.

131. Chicago Board of Trade v. United States, 246 U.S. 231 (1918). 
The "call" rule promulgated by the Board both established the "call" in order to provide a public competitive market to replace the private market that had grown up, and also prohibited members of the Board from purchasing or offering to purchase during the period between the close of the call, usually at about 2 p.m., and the opening of the regular session at 9:30 a.m. on the next business day, any wheat, corn, oats, or rye "to arrive" at a price other than the closing bid on the call. The result, of course, was to confine price competition to a portion of the day and to fix prices over the greater part of the day.

The significance of the rule, on those facts, is certainly equivocal. It is hard to see what legitimate purpose the Board had in allowing its members to trade overnight but fixing the prices at which they could do so, but certainly it is equally difficult to perceive an illegitimate intent to rig the market in stuch an apparently inconsequential restraint. Unfortunately, the government had, and persuaded the district court to adopt, an intellectually trivial theory of the case. Offering no evidence to show the purpose or effect of the price-fixing provision, the government rested upon the proposition which it later offered to the Supreme Court as dispositive of the case: "An agreement between men occupying a position of such strength and influence in any branch of trade to fix the prices at which they shall buy or sell during an important part of the business day is an agreement in restraint of trade within the narrowest definition of the term."132 The district court struck from defendants' answer allegations and excluded much evidence concerning the purposes underlying the rule. When defense witnesses testified in general terms to the benefits flowing from the rule, government counsel did not press the cross-examination to determine how the rule and the benefits were causally related. In fact, however, as the government's brief in the Supreme Court pointed out, ${ }^{183}$ most of the benefits claimed for the rule - claims which Brandeis accepted at face value - were not related to the price-fixing provision at all, but to the rule's establishment of the "call" as a public market. ${ }^{134}$

Brandeis, writing an opinion upholding the agreement, began his argument by rejecting "the bold proposition, that a rule or agreement by which men occupying positions of strength in any branch of trade, fixed prices at which they would buy or sell during an important part of the business day, is an illegal restraint of trade under the Anti-Trust Law."135 He went on, in a passage which has become famous, to hold that it had been an error for the trial court to strike the allegations and exclude evidence concerning the history and purposes of the "call" rule:

132. Brief for the United States, p. 9.

133. Brief for the United States, pp. 14-16.

134. If there was confusion, it probably arose from the fact that witnesses were permitted to testify to the benefits of the "call" rule without specifying whether they were praising the establishment of a public market or the fixing of prices overnight. This testimony got into the record despite the trial court's rulings, but, perhaps because of those rulings, the government did not trouble to cross-examine rigorously.

135. 246 U.S. $231,238$. 
$\ldots$ [T] he legality of an agreement or regulation cannot be determined by so simple a test, as whether it restrains competition. Every agreement concerning trade, every regulation of trade, restrains. To bind, to restrain, is of their very essence. The true test of legality is whether the restraint imposed is such as merely regulates and perhaps thereby promotes competition or whether it is such as may suppress or even destroy competition. To determine that question the court must ordinarily consider the facts peculiar to the business to which the restraint is applied; its condition before and after the restraint was imposed; the nature of the restraint and its effect, actual or probable. The history of the restraint, the evil believed to exist, the reason for adopting the particular remedy, the purpose or end sought to be attained, are all relevant facts. This is not because a good intention will save an otherwise objectionable regulation or the reverse; but because knowledge of intent may help the court to interpret facts and to predict consequences. ${ }^{136}$

This dictum is often quoted as the quintessential expression of the rule of reason, and apparently it struck the rest of the Court at the time as sufficiently orthodox. Thus, the catalogue of relevant inquiries may be taken as no more than examples of investigations into purpose and effect of the sort White advocated in the Standard Oil and American Tobacco cases. Such studies would certainly have made sense here since the "call" rule was neither obviously a cartel agreement nor clearly not one.

Yet there seems to be more to Brandeis' intention than that; there is a cast to the passage that is not entirely conventional. Brandeis phrases the test as whether restraint "merely regulates" or "may suppress." Unless the agreement be regarded as collateral and subordinate to another main, lawful transaction - and Brandeis did not suggest one - that distinction has a decidedly odd ring. It sounds as though regulation of competition - which seems difficult to differentiate from mitigation of competition - might be lawful as an end in itself. This impression is strengthened by Brandeis' reference to the "evil" which the restraint was designed to remedy. This is not the way one would speak of an ancillary restraint designed to implement another transaction. It has, rather, the flavor of language employed to justify the dampening of competition in order to produce "healthier" conditions. Though he was stating a general theory of the Sherman Act, moreover, nowhere in the quoted passage or elsewhere in the opinion does Brandeis mention or suggest the existence of any category of restraints illegal per se.

The conviction that Brandeis was advocating a deviant rule of reason, what Taft would have called a "sea of doubt," is reinforced by the remainder of the Board of Trade opinion. Brandeis held not only that the trial judge had erred in excluding evidence, which would have required a remand for a new trial, but went on to state that, even so, enough had been admitted affirmatively to demonstrate the regulation's legality. He asserted, without anything resembling adequate record support, that "the rule had no appreciable effect upon general market prices; nor did it materially affect the total volume of grain

136. Ibid. 
coming to Chicago."137 Brandeis went on to insist that the result of the pricefixing had actually been to improve market conditions. ${ }^{138}$ Although he cited improvements that seem to have been largely the results of the creation of a public market in the "call" session, and which had little relation either logically or in the record to the price-fixing regulation, the examples offered must be taken to indicate, because so offered, the ends which Brandeis considered would justify an agreement on prices. They include such purposes as the bringing of transactions into the open so that all buyers and sellers could obtain knowledge of market conditions, the distribution of business among larger numbers of persons, and the elimination of business risks. ${ }^{130}$ Another indication of proper motives for agreements lessening competition was given :

137. Id. at 240. There was no basis for this conclusion in the record and could hardly have been any, given the impossibility of showing by evidence what the volume of grain shipments to Chicago would have been in the same time period without the rulc. In any event, it would have been necessary to know whether sales had been shifted between sales "to arrive" and spot and future sales. Perhaps because of the trial court's vicw of the case, such questions had simply been passed over.

138. Brandeis appears to have culled from the record, and accepted at face valuc, conclusionary and often ambiguous 'statements made by defendants' witnesses. Those statements were never tested at the trial because of the position taken by the trial court, at the government's suggestion, that such evidence was immaterial and did not constitute a defense. Since he had held this view of the law to be erroneous, it seems remarkable that Brandeis should have accepted these untested assertions as conclusive support for his own views.

139. ... [W]ithin the narrow limits of its operation the rule helped to improve market conditions thus:

(a) It created a public market for grain "to arrive". Before its adoption bids were made privately. Men had to buy and sell without adequate knowledge of actual market conditions. This was disadvantageous to all concerned, but particularly so to country dealers and farmers.

(b) It brought into the regular market hours of the Board sessions, more of the trading in grain "to arrive."

(c) It brought buyers and sellers into more direct relations, because on the call they gathered together for a free and open interchange of bids and offers.

(d) It distributed the business in grain "to arrive" among a far larger number of Chicago receivers and commission merchants than had been the case there before.

(e) It increased the number of country dealers engaging in this branch of the business; supplied them more regularly with bids from Chicago; and also increased the number of bids received by them from competing markets.

(f) It eliminated risks necessarily incident to a private market, and thus enabled country dealers to do business on a smaller margin. In that way the rule made it possible for them to pay more to farmers without raising the price to consumers.

(g) It enabled country dealers to sell some grain to arrive which they would otherwise have been obliged either to ship to Chicago commission merchants or to sell for "future delivery."

(h) It enabled those grain merchants of Chicago who sell to millers and exporters, to trade on a smaller margin and by paying more for grain or selting it for less, to make the Chicago market more attractive for both shippers and buyers of grain.

(i) Incidentally it facilitated trading "to arrive" by enabling those engaged in these transactions to fulfill their contracts by tendering grain arriving at Chicago 
Every Board of Trade and nearly every trade organization imposes some restraint upon the conduct of business by its members. Those relating to the hours in which business may be done are common; and they make a special appeal where, as here, they tend to shorten the working day or, at least, limit the period of most exacting activity. ${ }^{140}$

This statement, by its terms not limited to organized exchanges, indicates that the shortening of hours was considered a good in itself and might be sufficient to justify an agreement not to compete during part of the day. This suggests that Brandeis believed that private regulation of competition might legitimately have other than economic aims; it might go beyond regulating, and thereby promoting, competition, to the achievement of non-economic goals. To that extent, a Sherman Act court would be required to balance economic goals against more broadly social or humanitarian goals.

The themes in Brandeis' Board of Trade opinion, then, are several and so skillfully woven together that they are difficult to disentangle. So far as its holding is concerned, the case can be viewed in quite conventional terms. The agreement on price may be seen as a restraint ancillary to a joint venture: the formation and maintenance of a public market for sales "to arrive." Defendants argued the case along these lines, though not in that phrascology, when they said that the call rule was no different than the ordinary restriction of exchange trading to certain hours. The analogy may be imperfect but perhaps it carried the Court, particularly since the government offered no explanation of the rule as a cartel arrangement. Brandeis did not disown this reasoning and, since he insisted that the rule had no impact upon market price and volume of grain sold, it is impossible to know for certain what he would have said had the rule not related to an organized exchange (or, to use another formulation, not seemed ancillary to a joint venture) or if it had obviously affected market price. Yet it seems a fair inference from the foregoing analysis of his opinion that he was prepared, in any event, to accord independent weight to market "improvements" such as bringing transactions into the open (a theory that might have legitimated the agreements in Trans-ifissouri and Joint Traffic) and to such goals as the spreading of business to more persons and the creation of leisure.

That this is an accurate reading of Brandeis is further demonstrated by his strong belief in the worthiness, and hence the legality, of resale price mainte-

on any railroad, whereas formerly shipments had to be made over the particular railroad designated by the buyer.

246 U.S. at $240-41$.

Of these claimed improvements, (a) through (h), insofar as they may be taken scriously, appear wholly or in large part to be due to the establishment of the call as a public market rather than to the price-fixing requirement of the call rule. Mrany of the advantages, moreover, were obviously imaginary. There was, for example, no demonstration in the record of the "fact" recited in (h) that grain merchants were able to trade on a smaller margin and therefore paid more for the grain or sold it for less. (i) had nothing to do with the rule in question but was due to a change in contract form.

140. Id. at 241. 
nance. Prior to his appointment to the Supreme Court he protested vigorously against its Dr. Miles decision: "President Wilson urged most wisely that, instead of sanctioning and regulating private monopoly, we should regulate competition. Undoubtedly statutes must be enacted to secure adequate and effective regulation; but shall our courts prohibit voluntary regulation of competition by those engaged in business?"141

It has been suggested, it seems justly, that Brandeis' eagerness to uphold many private regulations of competition led him to resort to rather sophistical economic reasoning, of which Board of Trade provides an example, when that seemed necessary. ${ }^{142}$ This sometimes clouded his basic rationale. But in its invitation to judicial subjectivity, as well as in the economic nature of its results, ${ }^{143}$ Brandeis' rule of reason bore an obvious kinship to the reasonable price standard advanced by White in 1897 and to the "sea of doubt" Taft warned against.

\section{The Persistence of Divergent Themes in the Rule of Reason}

After Chicago Board of Trade the major ground themes that sound in this area of antitrust had been laid down and there remained only their interplay and, perhaps optimistically, their eventual resolution. As of this moment, however, most of the early confusion concerning both goals and ecenomic analysis remains a prominent feature of the law.

It is true that Holmes' theory of the Sherman Act, as was probably to have been expected, has proved sterile and is forgotten. Brandeis' influence, however, continues in a variety of ways. His belief that the law should display explicit concern for non-economic values, while it seems to play an increasingly important role in other areas of antitrust, has found only peripheral lodgment in the law of price fixing and market division under Section 1 of the Sherman Act. There may be indications, however, that that belief will play a larger role

141. Brandeis, Competition that Kills, in Busrness - A Proressron 259 (1913).

142. In interpreting this and other private agreements, Brandeis employed the same method he utilized in upholding the state legislation against constitutional attack under the due process clause. Apparently, he implied a presumption of reasonableness to such agreements and required the Government to negate [demonstrate?] any anticompetitive purpose or effect by affirmative proof. As in the constitutional sphere, Brandeis buttressed the presumption by his ingenious ability to contrive a rational basis for the questioned arrangement.

Handrer, Antrtrust in Perspective 94 n.130 (1957). 'This same tendency in Brandeis' judicial philosophy is indicated by the summary and analysis of his opinions in several constitutional and Sherman Act contexts in Comment, Mr. Justice Brandeis, Competition and Sinallness: A Dilemma Re-Examined, 66 Y $\mathrm{ALE}$ L.J. 69 (1956).

There is thus an interesting contrast between Brandeis' willingness to stretch in order to tphold state statutes and his willingness to stretch to lessen the impact of the federal antitrust laws upon private regulations of competition. This may seem a contradiction in his philosophy of the proper roles of legislatures and courts, but perhaps the anomaly disappears or is cast in a different light when one realizes that in both cases Brandeis cxercised "his ingenious ability to contrive a rational basis" for the questioned statute or agrecment in order to uphold restrictions on the operation of the free market.

143. See pages $828,832-47$ infra. 
in the future. ${ }^{144}$ The extent to which Brandeis' notions are still operative in the law is somewhat obscured by the failure of the institutions which make, enforce, and apply the law to develop sufficient economic sophistication to distinguish consistently between agreements which "regulate" or eliminate competition for its own sake and those which do so as an inevitable incident in the creation of new efficiencies. It is thus sometimes difficult to know whether a particular decision is due to a Brandeisian view of the law's objectives or merely to bad economics.

The 1927 Trenton Potteries decision, ${ }^{145}$ a case in which Brandeis did not participate, contained an explicit repudiation of the broader implications of Chicago Board of Trade, and hence of Brandeis' approach to the rule of reason. Respondents, manufacturers and jobbers of vitreous pottery fixtures, had been convicted of violating the Sherman Act by forming a combination to fix prices and to limit sales to a special group of jobber respondents. The Court of Appeals for the Second Circuit reversed for errors in the conduct of the trial and the government brought the case to the Supreme Court.

Justice Stone's opinion for the Supreme Court, reversing the Court of Appeals, held not only that the trial court had properly refused to give as a jury instruction the passage from Board of Trade describing the rule of reason but that it had properly given a charge very similar to the proposition Brandeis had there rejected: ". . . the law is clear that an agreement on the part of members of a combination controlling a substantial part of an industry, upon the prices which the members are to charge for their commodity, is in itself an undue and unreasonable restraint of trade and commerce."1: The holding by the Supreme Court that the trial court had properly refused what Brandeis had offered, and had properly charged what Brandeis had denied, must be taken as an outright rejection of Brandeis' version of the law. To nail the point down, Stone quickly distinguished and drastically curtailed the Board of Trade rationale: "That decision, dealing as it did with a regulation of a board of trade, does not sanction a price agreement among competitors in an open market such as is presented here."147 Stone did not, however, specify the criteria of the rule of reason other than to state that the effect of an agreement upon competition was one.

This repudiation of Brandeis' justification for price fixing was made firmer in Justice Douglas' Socony-Vacuum opinion in which he rejected as a defense the need to eliminate "competitive evils." "If the so-called competitive abuses were to be appraised here, the reasonableness of prices would necessarily become an issue in every price-fixing case. In that event the Sherman Act would soon be emasculated. ..."148 And in footnote 59, where for some reason he placed the law made by the case, Douglas said, "Whatever economic justifica-

144. See text accompanying notes 160-74 infra.

145. United States v. Trenton Potteries Co., 273 U.S. 392 (1927).

146. Id. at 396 .

147. - Id. at 401.

148. United States v. Socony-Vacuum Oil Co., 310 U.S. 150, 221 (1940). 
tion particular price-fixing agreements may be thought to have, the law does not permit an inquiry into their reasonableness. They are all banned becatise of their actual or potential threat to the central nervous system of the cconomy." 149

Language of this sort could be cited from any number of cases from Trenton Potteries on. And yet, simultaneously there are cases which permit the elimination of competition by price fixing or market division or other agreements not only when it is an incident to the creation of new efficiencies by combination but also when it is done, or justified as necessary, to regulate competition in order to remove "competitive evils" or to protect small competitors.

The Appalachian Coals opinion ${ }^{150}$ is a classic example of the mixing of these two strains of antitrust. It is instructive to separate them and see their differences. Without the Brandeisian element the agreement in question there could never have been upheld, for the facts demonstrated a clear intent to cartelize and restrict output. In the trial court the government had won an injunction to prohibit 137 defendant producers of bituminous coal from combining to form and use an exclusive selling agency, Appalachian Coals, Inc. The producers owned all of the agency's capital stock, their holdings being in proportion to their production. Each producer, by a separate contract, designated Appalachian Coals an exclusive agent for the sale of its coal mined in Appalachian territory. Appalachian Coals agreed to establish standard classifications of coal, to sell all the coal of its principals at the best prices obtainable and, if all the coal could not be sold, to apportion orders upon a stated basis. Prices were to be set by the officers of the agency at its central office. In order to preserve their existing sales outlets, producers were permitted to appoint subagents who would sell upon the terms and prices established by Appalachian Coals and would be allowed eight per cent commissions by it.

Aside from the explicit price-fixing provisions, the use of a joint selling agency itself necessarily involved the establishment of uniform prices between the participating producers. Within any given grade the coal of the various producers was fungible and, as in any joint sales agency, economies of shipment, storage, and sale might on occasion have required commingling of the coal from various producers. It would hardly be practicable, in any event, for the selling agent to offer purchasers several different prices for identical batches of coal. Thus, an effect very much like an agreement on prices was inevitable, and would seem to be inherent in any joint selling agency where the products of the participants are fungible, or, in fact, are to any degree substitutable so that a shift in the price of one necessarily affects the price that can be gotten for the other.

Upholding this elimination of competition gave Chief Justice Hughes no difficulty: "The mere fact that the parties to an agreement eliminate competition between themselves is not enough to condemn it. ... The familiar illus-

149. Id. at $224 \mathrm{n} .59$.

150. Appalachian Coals, Inc. v. United States, 288 U.S. 344 (1933). 
trations of partnerships, and enterprises fairly integrated in the interest of the promotion of commerce, at once occur. The question of the application of the statute is one of intent and effect, and is not to be determined by arbitrary assumptions."151 Having determined, on the analogy of partnerships and other integrated enterprises, that the elimination of competition in the use of a joint selling agency was not per se unlawful (that is, not unlawful by its inherent nature), Hughes went on to examine defendants' share of the relevant market to determine whether their combination in a joint selling agency gave them power to affect market price ${ }^{\mathbf{1 6 2}}$ and to examine defendants' purposes to determine whether their ultimate intention was the elimination of competition or the achievement of other valid ends. ${ }^{163}$ Hughes concluded that the defendants would not possess power over prices, and among the purposes found were a number that involved the creation of new marketing and distribution efficiencies. ${ }^{154} \mathrm{He}$ recognized the similarity of the arrangement to a merger, stated that the same criteria applied, ${ }^{155}$ and held it lawful.

The reasoning to that point was consistent with the three-part test enunciated by White in American Tobacco. Had there been no more to the opinion or the facts, Appalachian Coals would rank as a major opinion in the development of the main tradition of the rule of reason. Unfortunately, however, it is a case with a split personality. The facts displayed an unmistakable intention by the producers to eliminate competition and stabilize prices, and Hughes' opinion, in addition to the reasoning already discussed, exhibited a Brandeisian willingness to judge how much "regulation" and elimination of competition, as an end in itself, was an allowable or even praiseworthy goal.

151. Id. at 360-61.

152. Id. at 367-73.

153. Id. at 366-67.

154. The district court found, for example, that among the purposes of the combuntion of defendants' selling functions in Appalachian Coals was the maintenance of an inspection and engineering department which would keep in close touch with customers "in order to demonstrate the advantages and suitability of Appalachian Coal in comparison with other competitive coals"; the mounting of an extensive advertising campaign to show "the advantages of using coal as a fuel and the advantages of Appalachian coal particularly"; the creation of a research department employing combustion engincers which would demonstrate "proper and efficient methods of burning coal in factories and in homes" in order to aid in the competition with substitute fuels; and the operation of a credit department which would build up a record as to the "reliability of purchasers." Id. at 366-67. It might also be supposed that an advantage of consolidation in a single selling agent would be the saving of costs in that the joint agent might require fewer salesmen, office workers, and so forth, than the total of all the producers separately.

155. The argument that integration may be considered a normal expansion of business, while a combination of independent producers in a common selling agency slould be treated as abnormal - that one is a legitimate enterprise and the other is not makes but an artificial distinction. The Anti-Trust Act aims at substance. Nothing in theory or experience indicates that the selection of a common selling agency to represent a number of producers should be deemed to be more abnormal than the formation of a huge corporation bringing various independent units into one ownership. Either may be prompted by business exigencies and the statute gives to neither a special privilege.

Id. at 377 . 
The coal producers' primary anticompetitive intent appeared on the face of their arrangement, for their contracts with the agent, Appalachian Coals, provided that, if all of their coal could not be sold, orders were to be apportioned among the participating producers. Since it would obviously be possible to sell all the producers' coal at the market price, particularly if one accepts their claim that they were but a small factor in the relevant market, the provision for rationing orders can only be interpreted as the establishment of a system of quotas which is essential where restriction of production is contem. plated. That such a restriction of production would not be a mere foolish gesture because of the number of other sellers in the relevant market is probably indicated by the fact that similar agencies were to be formed in other districts, including those which were competitive with Appalachian Coal. 160 The opinion, moreover, emphasized the deplorable condition of the coal industry and the "destructive practices" which aggravated that condition. The elimination of these practices was said to be one of the purposes of the combination, just as the regulation of competition had been said in Chicago Board of Trade to be aimed at the improvement of market conditions. But, just as the cited improvements there had little support in the record and less logical relation to the price-fixing aspect of the "call" rule, so, in Appalachian Coals, defendants' explanation of the destructive practices they were supposedly seeking to eliminate was so transparently nonsensical that it seems impossible the Court did not see through them. Perhaps it did, but chose to accept them anyway. A particularly outlandish argument, repeated straightface in the opinion, was that concerning the "pyramiding" of coal. This was said to occur when a producer authorized several persons to sell the same coal, and they in turn might offer it for sale to other dealers. Hughes quoted the district court's finding that, in consequence, "the coal competes with itself, thereby resulting in abnormal and destructive competition which depresses the price for all coals in the market."167 The suggestion was of course an absurdity. If one granted for the sake of argument that a network of dealers all offering the same ton of coal could depress its price and that this phenomenon cotild be so widespread as to depress the market price for coal, the net result would be more offers to purchase at the lower price than there were tons of conl forthcoming so that the price would immediately return to the level at which the amounts of coal offered and the amounts sought were equal and the market was cleared. Other "destructive practices" cited were of a similar transparency..$^{158}$

156. Id. at 366. Perhaps additional indication of an intent to affect prices beyond the extent which was inherent in the formation of the joint sales agency appears in the provision that the existing sales outlets were to be designated subagents and to conform their prices and terms to those set by Appalachian Coals.

157. Id. at 363 .

158. One such "destructive practice" was said to be the shipping of "distress coal" on consignment without prior orders. The argument was that purchasers' demand for coal was usually for particular sizes but that the production of the desired size entalled the 
The Supreme Court's opinion accepted the elimination of these supposedly destructive practices as a legitimate reason for combination, despite the fact that the producers' only real objection to the practices was that they tended to lower the market price. Hughes' opinion is not clear on the question of the legality of tampering with market price, partly, no doubt, because he was in the awkward position of approving attempts to alleviate depressed market prices by producers whom he had found were without sufficient market power to be able to fix prices. He sought to reconcile the conflict in a passage whose ingenuity and tone were reminiscent of the Chicago Board of Trade opinion:

The contention is, and the court below found, that while defendants could not fix market prices, the concerted action would "affect" them, that is, that it would have a tendency to stabilize market prices and to raise them to a higher level than would otherwise obtain. But the facts found do not establish, and the evidence fails to show, that any effect will be produced which in the circumstances of this industry will be detrimental to fair competition. A co-operative enterprise, otherwise free from objection, which carries with it no monopolistic menace, is not to be condemned as an undue restraint merely because it may effect a change in market conditions, where the change would be in mitigation of recognized evils and would not impair, but rather foster, fair competitive opportunities. ${ }^{169}$

The juxtaposition of the two rationales in Appalaclian Coals makes plain the difference between the Peckham-Taft-White and the Brandeis versions of the rule of reason. Movement from the former to the latter involved a shift from a consumer-oriented rule to a producer-oriented rule. The former rested

production of other sizes which had not been ordered. Usually there were not storage facilities at the mine and the unwanted sizes were placed in cars on the producers' trachs. The tracks would sometimes become so congested that cither production must be stopped or the cars moved regardless of demand. This led to the practice of shipping unsold cosl to billing points or on consignment to the producer or his agent. If the cosl was not sold by the time it reached its destination, and was not unloaded promptly, it became subject to demurrage charges which might exceed the amount obtainable for the coal unless it were sold quickly. This "distress coal," which was of all sizes and grades and of substantial quantity, was found to press on the market at all times and to aggravate the depressed condition of prices. Id. at 362-63. One of the stated purposes of the formation of Appalachian Coals was to stop the practice of shipping coal on consignment without prior orders. This of course was a clear admission of intent to restrict output, to increase prices by holding coal off the market. That intention is not less wrongful because of the argument advanced as to "distress coal." It is simply another form of the familiar spectre of "ruinous competition." If the production of one size of coal inevitably requires the production of other sizes, that is an economic phenomenon of a type familiar to many industries. So long as it proves profitable for a producer to continue to operate in the manner deseribed, tat:ing his total profits and losses from all sizes of coal, there is no problem. Should it prove unprofitable, it means simply that too many producers, or, more accurately, too many resources are engaged in the production of coal. The best response is to allow the distress to continue until the excess resources have moved out. Restricting the output prevents that and continues the misallocation of resources. Defendants should have lost the case on their their own argument about "distress coal" alone.

159. Id. at $373-74$. 
justification for combination in the achievement of efficiencies; the latter found justification for combination in the greater comfort or security of the producers.

This Brandeis rule of reason may also be discerned in more recent cases. It appears, for example, rather unexpectedly in Justice Douglas' reversal in Paramount ${ }^{160}$ of the district court's decree that all defendant distributors license their films only on a competitive bidding basis. Among the reasons Douglas gave was that competitive bidding would favor exhibitors with the "longest purse" to the detriment of the "smaller independents."101 Something of the same spirit may perhaps be discernible both in subsequent lower court decisions and in the government's enforcement efforts concerning the motion picture industry. One of the reasons lower courts have, for example, seemed sympathetic to "splits" - agreements between exhibitors in individual cities to divide particular distributors' film offerings so as not to bid against each other - appears to be that competitive bidding might force some exhibitors out of business. ${ }^{162}$ This fear seems also to have stayed the government from any all-out attack on the "split" system of film distribution. ${ }^{103}$ This is in sharp contrast to the usual insistence of the courts and the government on the per se illegality of horizontal market division. ${ }^{164}$

Justice Douglas' White Motor ${ }^{165}$ opinion occupies a somewhat ambiguous position with respect to these issues. The case may reflect a tension between the Douglas of Socony-Vacumm and the Douglas of Paramount. Quoting from another case, Douglas said in White Motor that the category of per se violations was composed of "agreements or practices which because of their pernicious effect on competition and lack of any redeeming virtue are conclusively presumed to be unreasonable and therefore illegal without elaborate inquiry as to the precise harm they have caused or the business excuse for their use." 100 Falling within this class of restraints were tying arrangements, horizontal market divisions, group boycotts, and price fixing, both vertical and horizontal. This, however, was the Court's first experience with market division (by territorial limitation and by customer allocation) in a vertical arrangement, and, said

160. United States v. Paramount Pictures, Inc., 334 U.S. 131 (1948).

161. Id. at 164 .

162. See, for example, the remarks of the court in Brown v. Western Massachusetts Theatres, Inc., 288 F.2d 302, 305 (1st Cir. 1961). The desire to soften competition in order to protect exhibitors seems also to be a recurring theme in other motion picture industry litigation. See Comment, An Experiment in Preventive Antitrust: Judicial Regulation of the Motion Picture Market Under the Paramount Decrees, in a forthcoming issue of the Yale Law Journal.

163. So far the government appears to have confined itself to efforts to ensure that all exhibitors in an area who wished to do so were permitted to join in "splitting" arrange* ments on an equitable basis. See letter of Lee Loevinger, Assistant Attorney General, Antitrust Division, to Edward Bennett Williams, attached as an appendix to Petitioner's Bricf in Viking Theatre Corp. v. Paramount Film Distributing Corp., 378 U.S. 123 (1964).

164. White Motor suggests that "splits" might be lawful if analyzed as vertical restraints but most of the cases appear not to have been litigated or decided on that basis.

165. White Motor Co. v. United States, 372 U.S. 253 (1963).

166. Id. at 262 . 
Douglas, the Court knew too little of its actual economic impact to fashion the rule of per se illegality that would have been necessary to sustain the summary judgment granted by the district court. But at this point the opinion falters. It does not specify the contours of the investigation to be conducted by the district court upon remand. Instead, as a statement of the rule of reason, which "normally requires an ascertainment of the facts peculiar to the particular business," Douglas quoted, without comment, the full passage from Brandeis' Chicago Board of Trade opinion. ${ }^{107}$ Other than its extremely vague, perhaps meaningless, distinction between the regulation and the suppression of competition by private agreement, this passage offers very little guidance concerning the criteria that control legality, and what it does offer seems incompatible with the existence of any per se rule. Yet it stands, inscrutable, at the center of the White Motor opinion. Perhaps its use merely signifies and compensates for the Court's continuing inability to generalize in a meaningful way the economic standards that control the incidence of the per se rule in this area. This is a traditional role of the Board of Trade opinion. But perhaps the use of that opinion signifies more, for, subsequently, in suggesting some of the justifications that might be open for arrangements such as White's, Douglas introduced values which sound Brandeisian: the arrangements might be "allowable protections against aggressive competitors or the only practicable means a small company has for breaking into or staying in business ... and within the 'rule of reason" "109 and, as an analogy from a different statutory setting, a "merger that would otherwise offend the antitrust laws because of a substantial lessening of competition has been given immunity where the acquired company was a failing one."1co

Concern for the preservation of small competitors, as a value in itself, is inconsistent with the stress placed by the main tradition, reflected in the per se rule, on permitting the forces of competition in the market to work themselves out. If the opinion meant simply that the main purpose and effect of the vertical allocation of territories and customers was the creation of effciency rather than the elimination of competition for its own sake, then that should be justification enough, whether or not the added efficiency was within the vague classes of "allowable protections against aggressive competitors" or "the only practicable means a small company has for breaking into or staying in business." Insofar as these criteria raise any considerations other than the general desirability of increased efficiency they are suspiciously similar to the considerations which moved Brandeis in Chicago Board of Trade and Hughes and the Court in Appalactian Coals.

167. Ibid.

168. Id. at 263, citing Brown Shoe Co. v. United States, 370 U.S. 294, 330 (1962), and United States v. Jerrold Electronics Corp., 187 F. Supp. 545, 560-61 (E.D. P3. 1960), aff d, 365 U.S. 567 (1961).

169. Id. at 263-64, citing International Shoe Co. v. Federal Trade Commission, 230 U.S. 291, 302-03 (1930). 
The approach here termed Brandeis' is, of course, by no means confined to his opinions. Traces of it are to be found throughout the body of the antitrust laws. In its most specific form, this approach may be defined as a willingness on the part of courts to give independent weight to the preservation and welfare of small business, even when that involves sacrificing to some degree the interests of consumers. ${ }^{170}$ Chicago Board of Trade reflects this tendency by attaching significance to the belief that the restraint under review spread business to more traders and enforced a degree of leisure. Similar concern for small business as an independent value may be seen not only in the examples already cited - Appalachian Coals, Paramount, other motion picture litigation, and, perhaps, White Motor - but in a number of other cases, including Judge Learned Hand's opinion in United States v. Aluminum Co. of America ${ }^{171}$ and, increasingly, in merger opinions such as Brown Shoe Co. \%. Unitcd States. ${ }^{172}$

Stated more generally, the Brandeis tradition may be described as the inclination on the part of some courts to consider a very broad range of values, even noneconomic values, in the decision of antitrust cases. Conspicuous examples of this were Judge Learned Hand's opinion applying First Amendment considerations through the Sherman Act in United States $v$. Associated Press, ${ }^{173}$ and Justice Frankfurter's concurring opinion in the Supreme Court affirming the decision on the same grounds. There may be reason to believe as well that the enforcement policy pursued by the government is sometimes influenced by considerations other than consumer welfare. ${ }^{174}$ Because this article focuses primarily on problems of price fixing and market division, consideration of the Brandeisian tradition will be confined to its influence in those areas. Much of what is said could, nevertheless, be applied broadly to the influence of that tradition throughout antitrust.

It seems clear, then, that to some undefined extent the rule of reason today continues to hold within itself the separate and very different policy strands of the Peckham-Taft-White tradition and of the Brandeis tradition. While confusion may have had its uses, it seems time that the rule of reason in this most basic of areas be clarified and made consistent.

170. That this was a strong element of Brandeis' judicial philosophy is demonstrated in Comment, Mr. Justice Brandeis, Competition and Smalluess; A Dilemma Ro-Etraminted, 66 YALE L.J. 69 (1956).

171. 148 F.2d 416 (2d Cir. 1945).

172. 370 U.S. 294 (1962).

173. 52 F. Supp. 362 (1943).

174. In addition to its positions in motion picture industry litigation, see notes 162 and 163 supra, the government has, for example, apparently sometimes refrained from prosecuting concerted boycotts by farmers' groups which were intended to gain higher than market prices for their products. Various industry codes of ethics or standards for products have also often gone unchallenged, seemingly because of approval of the motives of the industry, despite the fact that a mode of competition which some consumers liked was thereby eliminated. Agreements on cigarette advertising, and types of motion pictures and television programs come at once to mind. 


\section{Assessment of the Poltcy Objectives \\ of the Divergent Themes in the Rule of Reason}

A necessary step toward coherent doctrine is the elimination of the confusion concerning goals which seems partially responsibie for the law's vacillation between the Peckham-Taft-White tradition and the Brandeis version of the rule of reason. The superiority for the law relating to price fixing and market divison of the policy objectives of the main tradition seems clear. The point requires discussion, nevertheless, because the values expressed by Justice Brandeis, whether due to his prestige or for independent reasons, have continued in the modern cases and in enforcement policy.

\section{The Policy Inherent in the Main Tradition}

Judges in the main tradition have never been very articulate about the ultimate values served by the law of price fixing and market division. It seems clear, nevertheless, that implicit in the approach of the main tradition of the rule of reason is the policy of assisting the economy to maximize wealth (defined as consumer want satisfaction).

It need not be demonstrated further that the Peckham-Taft-White view rejected the reasonable price formulation of the law and that it held per se illegal all agreements whose sole purpose or effect was to suppress competition. None of the cases of that tradition, however, took the preservation of competition as the law's sole guide. They could hardly have done so, since as Justice Holmes demonstrated in his Northern Securities dissent, devotion to the principle that persons who can compete may not combine would require the dissolution of all productive units in our society consisting of more than a single person.

Though inaccurate, it is natural to slip into the shorthand of speaking of the purpose of the antitrust laws as being the preservation or the promotion of competition because the event that triggers the law is always the elimination of competition by agreement. Yet it is a loose usage that has its dangers, for it invites the further erroneous conclusion that the elimination of competition by agreement must always be illegal. This sort of slippage seems to account for Justice Clark's dissent in White Motor and for Justice Douglas' statements about horizontal agreements in his Penn-Olin dissent.

Peckham avoided this pitfall by conceiving the evil banned through the term "restraint of trade" as the suppression of competition in the general market. Taft escaped it with his concept of ancillarity, and White did so with his distinction between agreements normal in trade and those creating the evils of monopoly. Not every elimination of competition, of course, entails the consequences of monopoly. Yet, if these judges avoided the unworkable rigidity of a per se rule against all eliminations of competition, on one side, they were less successful, on the other, in articulating a general theory of permissible eliminations of competition. Peckham stated no useful general rule, nor did White, beyond the idea that normal contracts not attended by the evils of 
monopoly were lawful. Taft offered only the unhelpful generalization that lawful agreements not to compete were those necessary to secure to a party the "legitimate fruits" of his contract or to protect him from "an unjust use of those fruits by the other party."

These early cases of the main tradition, however, contain lines of approach from which we can extrapolate the policy that necessarily underlies the decisions. This is possible and legitimate even though that policy may never have been explicitly formulated in any judge's mind. The policy, as already indicated, is the maximization of wealth or consumer want satisfaction. It may be derived from the distinction the Sherman Act courts made between cartels and mergers, from the examples of the lawful elimination of competition given by the courts, and from their insistence that competition played a central role in the law.

The difference in treatment accorded by the Sherman Act to loose and integrated combinations has been termed "one of the most provocative anomalies in the law."176 It is true of course that the law has long regarded cartels and mergers - which is what is meant here by loose and integrated combinthtions - as polar models. From Trans-Missouri on, cartels have been treated by the main tradition of the law as beyond any possibility of justification, while the greater solicitude of Sherman Act courts for mergers is well known. Even under the more stringent provisions of amended section 7 of the Clayton Act horizontal mergers are certainly not per se illegal. The law, therefore, has treated and continues to treat differently two forms of agreement which are alike in that they eliminate competition. The disparity is indeed provocative but, as analysis demonstrates, it is far from anomalous. It is, more accurately, basic to any economically rational antitrust policy. ${ }^{170}$ Moreover, it is explainable only in terms of a policy of wealth maximization. The only difference between the two forms of elimination of competition which suggests a more lenient attitude toward mergers is that cartels contain no possibility of the creation of efficiencies, their sole purpose and effect being the restriction of output, while mergers may or may not enable the achievement of efficiencies. ${ }^{177}$

175. Jaffe \& Tobriner, The Legality of Price-Firing Agrecments, 45 HARv. L. REv. 1164 (1932).

176. Absent a distinction between cartels and mergers, the law could only hold both per se lawful, hold both per se unlawiul, or attempt to hold some cartels as well as some mergers lawful. The first possibility would destroy any reason to have an antitrust policy; the second would lead to the useless destruction of an important means of creating efficiency, and, if the economic identity of mergers and other forms of combination be admitted, would, as Holmes saw, require the dissolution of almost all productive units. The third possibility requires the making of distinctions among kinds of cartels and thus introduces the irrationalities of what is here termed the Brandeis rule of reason. For a discussion of the irrationality of that approach, see pages 834-35 infra.

177. It seems difficult to imagine another value which would suggest greater toleration for mergers than for cartels since, aside from their efficiency-creating potential, mergers might seem less socially desirable. They eliminate competition between the agrecing parties more completely, limit their freedom more thoroughly, and they are more permanent. 
The operative significance thus given to efficiency in the production and distribution of goods and services necessarily derives from a desire to increase the wealth of the society.

A similar, though perhaps less certain, inference can be drawn from the examples of lawful eliminations of competition given by Peckham and Taft. Peckham's list in Joint Traffic was particularly suggestive because most of it - the formation of corporations for business or manufacturing purposes, the contract of partnership, the appointment by two or more producers of the same person to sell their goods on commission, a lease or purchase by a farmer, manufacturer or merchant of an additional farm, manufactory or shop - consisted of examples of consolidations which, like mergers, are capable of creating efficiencies. Similarly, the example that Taft justified by policy argument, the agreement of partners not to compete during the partnership, was an instance of consolidation, and Taft found it valid because it aided the partners to accomplish "a union of their capital, enterprise, and energy to carry on a successful business, and one useful to the community." This explanation is phrased in terms of wealth-creating efficiencies. Some of Peckham's and Taft's other examples, such as the covenant by the seller of a business not to compete with it subsequently, are not perhaps so obvious, and may upon analysis turn out to be incorrect applications, but they appear to reflect the same policy. The justification for the covenant ancillary to the sale of a business, for example, is often said to be that without it the business could not be sold and so might be carried on less effectively by the aging original owner or perhaps be liquidated. This, too, is an explanation couched in terms of desire for more efficient resource use.

Finally, however, the law's avowed concern with the promotion of competition indicates that wealth is the ultimate goal of the law, for, as the courts have recognized in making the exceptions and distinctions just discussed, the policy of promoting competition is only half a policy. Competition is the name of a process, not of an ultimate desideratum, and so implies a further value. There are a variety of reasons why competition is popularly imagined to be useful - it is said, for example, to assist dispersion of political and social power in the community, to spur technological innovation, and so on - but in economic analysis competition is most admired as one means of assisting in the creation of wealth, or, to say the same thing, the maximization of the satisfaction of consumer wants. Moreover, - and this is a crucial consideration - if the alternative values mentioned had been viewed by the courts as underlying to any significant degree the policy of preserving competition, there would have been available no firm criteria for the decision of particular cases. The fact that the courts have insisted upon such criteria, as will be shown in the discussion of the superiority of the main tradition to the Brandeis tradition, indicates that they could not have given weight to these alternative values. A policy of dispersing power (of the non-market varieties mentioned) has no built-in stopping place short of grinding society down to 
an aggregation of individual producers. There is no counter consideration which could inform a judge when some other value should override that of dispersing private power without involving him in the grossest sort of political judgment. The counter consideration cannot be efficiency because there is no criterion for choosing between efficiency and dispersal of power when the two conflict. They have no common denominator. The goal of promoting innovation is ruled out not only because it seems inconsistent with the main tradition's stress on the per se concept, but because there exists no science or set of meaningful criteria which indicates how much competition or elimination of competition is most effective in reaching the goal. Nor are there any criteria fit for judicial employment which even suggest whether, in a given case, it would be desirable to sacrifice more or less consumer satisfaction of other wants by devoting more or fewer resources to the promotion of innovation.

It is only when competition is viewed as subordinate to the ultimate value of creating wealth that there exists a social science - that of economics which courts may properly use to measure the amount of competition that is desirable. Though the estimate may often be rough, basic economic concepts suggest ${ }^{\circ}$ such criteria as the degree of fusion of the productive efforts of the parties, the amount of competition which must be eliminated to attain that fusion, the market share created and probable speed of entry of new competitors into the market as the means for judging whether the net effect of a specific agreement or combination is likely to be efficiency or restriction of output. Net effect upon wealth is the common denominator which permits judicial comparison of elimination of competition and efficiency in the decision of cases. There is thus provided a conceptual apparatus able to accomplish what Holmes thought could not be done if competition were a concern of the law - it stops the policy of promoting competition short of the complete atomization of society. And it is an apparatus capable of locating and describing the stopping point so that antitrust attains the virtues appropriate to good law by becoming capable of giving fair warning to those who must obey, susceptible of principled administration by the courts that apply it, and able to divide with tolerable precision conduct which is socially advantageous from that which is socially disadvantageous.

These matters will be taken up after a short discussion of the policies seemingly implicit in the Brandeis tradition of the rule of reason.

\section{The Policies Underlying the Brandeis Tradition}

The policies which find expression in the Brandeis rule of reason are somewhat more difficult to isolate and identify. Both in Brandeis' opinions and in that aspect of Hughes' opinion in Appalachian Coals which derives from Brandeis, there is an intertwining of policy arguments that make the position difficult to capsulate. This difficulty, as has already been suggested, may be an element of strength in the Brandeis tradition, making it both more 
useful for courts seeking escape from an overly confining per se formula and more difficult to attack directly as containing values not properly implemented through antitrust.

Staying clear, for the moment, of the wide range of social values that are sometimes ascribed to Brandeis and sticking to those goals his opinions singled out as appropriate for the rule of reason, it seems possible to discern several discrete elements. In Brandeis' view, agreements eliminating or "regulating" competition may be saved from illegality because they: (1) Spread the available business among more firms; (2) achieve some purpose with a "special appeal," such as shortening the working day or limiting the period of most exacting activity; (3) spread information concerning market conditions; or (4) lessen risks, perhaps thereby enabling the charging of lower prices. If Appalachian Coals is classified as in large part within the Brandeis tradition, we may add, (5) make competition more "healthy" by ridding the market of particular "competitive evils" or "abuses."

The last three effects mentioned need not be at odds with a policy of maximizing consumer want satisfaction. The spreading of information does contain the possibility of increasing efficiency so that a question in each case would be whether some elimination of competition was necessary to that purpose or whether the spreading of the information was merely a pretext for an elimination of competition. A similar question could be asked about agreements whose benefit is said to be the elimination of risk. The elimination of "competitive evils" is an ambiguous goal, not inherently outside the values of the main tradition. The difficulty with it is that, as in Appalachian Coals, the "evil" to be eliminated almost invariably turns out to be competition. When that is the case there seems no difficulty in rejecting the policy as inconsistent with consumer welfare, though an occasional court may have diffculty in penetrating the vocabulary and specious economic reasoning to perceive the cartel nature of the agreement.

The other two factors - spreading the business among more persons, and the achievement of other appealing purposes - are those that are probably most distinctive in the Brandeis approach. They represent both that tradition's specific concern for small business and its more general toleration or encouragement of a continuing value-choosing role for the courts. It is the contention here that Brandeis' introduction of considerations which run counter to the policy of maximizing consumer want satisfaction has no proper place in the rule of reason.

\section{The Superiority of the Main Tradition's Policy}

The policy of maximizing wealth is preferable to the policies of the Brandeis tradition for implementation by the law of price fixing and market division because: (1) The courts are required to make only distinctions which correspond to economic reality; (2) the wealth-maximizing policy is better suited to the scope, nature, and ease of administration of the law; (3) the task of 
selecting the basic values to be implemented is given to the proper organ of government, the legislature, and not left for case-by-case selection by the courts; and (4) the law is provided with standards of the requisite certainty.

\section{The Economic Reality of the Distinctions Required}

It is clear that there exists an objective economic difference between an agreements whose sole purpose and effect is to suppress competition so that greater profits may be made through a restriction of output and an agreement whose sole purpose and effect is to increase profits through the achievement of greater efficiencies in production and distribution. They differ in their impact upon consumers, which is the ultimate criterion of the main tradition. Thus, there is a real difference between an agreement among 100 producers to sell at the same price and an agreement between two of them to employ a common sales agent. And this difference is not destroyed by the fact that it is possible to imagine difficult cases, such as the agreement by 50 to use one sales agent and by the other 50 to use a second sales agent.

The distinctions of the Brandeis tradition, however, seem not to inhere in the phenomena under observation so much as in the vocabulary of the tradition. The suggestion in Chicago Board of Trade that an agreement on prices may be lawful where it operates to spread the business to more firms does not offer a useful distinction between types of price-fixing or marketdividing agreements. By eliminating competition and raising the rate of return all cartel agreements may spread the business. They make it likely that more firms will survive, and, indeed, that more will enter the industry. There is, therefore, not one kind of cartel that spreads business and another kind that does not. If the suggested distinction cuts anywhere, it is in favor of all cartel agreements and against agreements such as partnerships and joint sales agencies which, by creating efficiency, tend somewhat to concentrate rather than spread business. ${ }^{178}$ Here the Brandeis tradition seems either to suggest distinctions which do not exist or else to prefer the restriction of output inherent in cartelization to the creation of efficiency.

The achievement of other "appealing" purposes, of which the creation of leisure by the limitation of business hours may be taken as typical, usually involves an attempt to achieve benefits for the agreeing parties. These agreements, however, are indistinguishable in principle from ordinary cartel agreements. Leisure and money are merely different forms of income. When they are obtained by agreed restrictions of output at the expense of consumers there seems no valid way to distinguish between them.

It is, presumably, more likely that a judge in the Brandeis tradition would uphold an agreement by automobile dealers to close on Sundays than an agree-

178. Thus it may be significant that Justice Douglas in White Motor suggested as an appropriate test whether the restrictions in question enabled a relatively small competitor to survive. The idea seemed to be that the creation of efficiency through such restraints might be limited to smaller and presumably otherwise less efficient companies. This may be a notion of spreading the efficiencies as a way of spreading the business. 
ment by the same dealers to add $\$ 50$ to the price of each car. The difference that seems to exist between the cases on first impression, however, disappears under analysis. In addition to the fact that both are limitations upon competition whose sole purpose is to increase income by restricting output, it is obvious that the parties can switch the results of the agreements. Auto dealers with Sundays off can work elsewhere on those days; and dealers with higher prices per car can elect to take their increased income in the form of Sundays off. The Brandeisian distinction between the two forms of agreement really rests upon the unanalyzed difference between the psychological associations relating to leisure and money. A court that takes the difference seriously ought to decide the automobile dealer cases only after learning whether the free Sundays were used for laudable or for vicious purposes, and whether the increased income was given to charity and spent on the children's education or squandered in nightclubs. Aside from this sort of test, which we are unlikely to import into the antitrust law or to entrust to courts, there is really no valid economic distinction on the producer side between any cartel and the agreement Brandeis found "appealing."

From the consumers' point of view such agreements are also indistinguishable. Consumers who lose the convenience of shopping on Sunday are deprived of something that is as much an economic good as is $\$ 50.170$ There is no acceptable way for a judge to decide that a restriction in the offering of a convenience is any less objectionable than a restriction in the number of automobiles sold.

The Brandeis approach, therefore, either becomes a rule of per se legality for cartel agreements or else degenerates into the making of subjective distinctions that do not correspond to any objective and significant differences in the phenomena concerned.

\section{The Scope, Nature, and Ease of Administration of the Law}

Though it may not by itself be a conclusive point, it is surely preferable that the policy read into a law be one which the law by its structure and coverage is able to implement efficiently. This consideration, too, favors the main tradition of the rule of reason.

Any law will, of course, be most effective if it deals with all or most of the instances of behavior which are directly relevant to the values it seeks to maximize. Section 1 of the Sherman Act is thus better suited to implement a policy of wealth maximization than a broad, open class of values which the courts would presumably be free to choose and implement under any generally Brandeisian approach. Two factors relating to the Act's scope and nature indicate its greater suitability as a tool of wealth maximization: (1) It scans only the field of contracts, combinations, and conspiracies in restraint of trade; and (2) it is entirely prohibitive. The pertinence of the first consideration lies in the fact that the described agreements and combi-

179. An economic good is here defined simply as something that consumers want. 
nations comprise only a minor segment of the full range of private actions and inactions which may advance or impede the variety of social values which a judge of the Brandeis tradition might find attractive. Even a value so closely related to trade and commerce as the creation of leisure may not be effectively dealt with in the context of agreements. Traders who refuse to close on Sundays or who work long hours may never make an agreement that can be reached by the Sherman Act but may, nevertheless, sacrifice not only their own leisure but that of their less industrious rivals. The problem, if it is one, can be dealt with better by Sunday closing laws or legislation regulating hours of trading or work. If section 1 of the Sherman Act is only a haphazard and inefficient means of promoting such values, however, it is well suited to the policy of wealth maximization because the events which trigger it - agreements and combinations restraining trade - constitute probably the primary means by which traders seek the market control necessary to the restriction of output. ${ }^{180}$

The second consideration - the wholly prohibitory nature of the Sherman Act - means that it is effective only to screen conduct which private parties themselves initiate. The law is wholly unable to serve values which must be implemented by coercing or inducing affirmative conduct that the self-interest or capabilities of private persons do not cause or permit them to undertake. It is somewhat difficult to cite examples to clarify this point because the Brandeis tradition has never flowered sufficiently to indicate the breadth of the values that courts might choose to implement under it. To choose a perhaps not unlikely hypothetical related to commerce, one can imagine that a Brandeisian judge might be impressed with the idea that the family farm and the way of life it is thought to involve are important to the social and political health of the society. This is a notion very like the idea that small business is socially, if not always economically, desirable. These ideas might suggest that agriculture and other industries populated by small units should be permitted to cartelize. If, however, the members of such an industry choose not to cartelize, or if their numbers or other factors, make cartelization unfeasible, the passive nature of the Sherman Act would render the judge powerless to implement the chosen value. It is, in fact, likely that it is precisely those industries characterized by many small producers that a Brandeisian judge would simultaneously most wish and be least able to help. The welfare of industries so structured is thus better left to laws - such as direct

180. Section 1 of the Sherman Act, of course, actually speaks of contracts, combinations and conspiracies in restraint of trade. If this were read broadly, without regard to the preservation of competition, then the law would apply to all agreements relating in any way to trade, for, as Brandeis noted in Chicago Board of Trade, every contract restrains. To read the Act this way would expand its scope and make it more useful for the implementation of a variety of broad social policies, but it would be tantamount to a delegation to judges to exercise the entire commerce power through the Sherman Act. 
subsidies or tax relief - which affirmatively encourage the desired form of activity. There seems no rational design in entrusting to judges a free valuechoosing role under a statute which haphazardly limits their effectiveness to those values which by chance happen to be capable of implementation through a wholly prohibitive law.

It does make sense, however, to give judges a prohibitory law when the value to be maximized is wealth. Producers destroy, as well as create, the wealth of society in large part through the integration of activities and facilities - that is, through agreements and combinations. The net effect is destruction of wealth when the integration's chief purpose or effect is the restriction of output. Creation of wealth occurs when the net effect is the creation of efficiency. Since producers are powerfully motivated by selfinterest to attempt both kinds of integration, we may confidently rely upon their affirmative actions to bring all relevant conduct to the passive screen of a statute which is so drawn or interpreted as to cover all forms of integration which eliminate competition and to strike down only those whose net effect is to decrease wealth. When it is keyed to wealth creation, in fact, the Sherman Act's passive or prohibitory nature becomes one of its prime virtues. Affirmative wealth-creating behavior cannot effectively be commanded by courts at the instigation of public prosecutors. The opportunities for effciency-producing integrations and the forms they should take are matters obviously better left to the superior numbers, information, and incentive of entrepreneurs.

Assuming the propriety of the broad social values mentioned above and others like them, it seems clear that they are not effectively implemented by a law which is both keyed to agreements and combinations and entirely prohibitive, but are better promoted by statutes such as those dealing with subsidies, tax relief, minimum retail markups, Sunday closing, wages and hours, safety standards and the like.

The choice of the wealth-maximization policy has the additional benefit of making the law more easily predicted, enforced, and applied. This touches upon the whole topic of vagueness and uncertainty, but here it is necessary to refer only to the fact that the policy of wealth maximization leads naturally to a broad and clear category of agreements illegal per se and to the use of objective criteria outside the per se area, while the Brandeis approach does not. In the main tradition, agreements which eliminate competition and have no tendency to create efficiency are illegal without more and the court's only task is to discover whether the alleged agreement exists. The benefits of a broad per se category in ease of enforcement and predictability are so great that its legitimate availability constitutes one of the main tradition's chief assets.

The problem is more difficult where the elimination of competition is plausibly claimed to be indissolubly linked to the creation of efficiency. The 
court may then resort to economic analysis to decide whether the claimed connection exists, and use such indicia as market share and ease of entry into the industry to determine whether the net impact of the arrangement will be to the benefit or detriment of consumers.

The Brandeis approach has no natural place for a per se rule. The main tradition's policy of wealth maximization requires no balancing in a cartel case because the effect of the agreement is only to restrict output. But the Brandeis tradition requires comparison of benefits to producers and benefits to consumers. Since the elimination of competition by agreement always benefits some producers a full trial and a balancing operation are required before anly agreement may be held unlawful. An additional contrast to the main tradition's balancing operation outside the per se area in cases involving both the eliminttion of competition and the creation of efficiency is that the Brandeis approach does not lend itself to objective economic criteria. A court using the Brandeis rule of reason could perhaps attempt to cure these objections, though necessarily creating others simultaneously, by drawing hard, arbitrary lines as to permissible behavior. Thus, it might decide that though agreements to take time off were usually lawful, agreements on prices were always illegal. Aside from the objection that the benefits of a per se rule had been purchased at the expense of economic rationality, this procedure would be likely to achieve only limited success, for it would merely invite cartelists to take their additional income in approved rather than disapproved currency. The seeming flatness and effectiveness of the rule would thus be largely illusory.

The existing scope and nature of the Sherman Act, as well as considerations of effective administration, thus indicate that the statute is better suited to implement the policy of wealth maximization than the policies underlying the Brandeis approach.

\section{The Roles of the Courts and the Legislature in Choosing Values and Making Interpersonal Comparisons}

Because the main tradition serves the single, unchanging valtue of wealth maximization it does not require the courts to choose or weigh tultimate values in the decision of individual cases or in the continuing evolution of doctrine. Neither are the courts involved in making comparisons of and choices between persons and groups of persons. Their decisions will, of course, necessarily affect the distribution of income both as between groups of producers and as between particular producers and consumers, but the courts are not permitted by the main tradition to take these effects into account in the decision of cases. In cartel cases, of course, the per se concept eliminates any problem of weighing or comparison. Outside the per se area, the courts consider only the benefit of consumers as a class by considering the probable net effect of the elimina- 
tion of competition and the creation of efficiency. The courts are thereby enabled to be impersonal in an important and desirable sense.

The Brandeis tradition lacks these virtues. Unless it legitimizes all cartels, it requires the courts continually to choose values and to make political choices between classes of citizens. Brandeis did not suggest how courts were to choose values, merely remarking that restraints tending to shorten the business day made a "special appeal" and assuming that the distribution of business to a larger number of persons was desirable on its face. Other judges working in this tradition would presumably feel free to decide what values appealed to them from time to time. The choice of ultimate values, however, is usually regarded as a function of the legislature and not of the courts. This is particularly important when it is realized that the implementation of such values is not costless and necessarily involves taxing some individuals to benefit others. The decision by a court to permit grain traders to increase their leisure by agreement, for example, or to permit coal producers to stabilize market price, or to forbid large manufacturers to achieve efficiencies in ways open to their smaller rivals, is to decide in each case to redistribute income from consumers to particular favored producers and also, in some cases, to take it from some producers and give it to others. This means that in each case the court is involved in income redistribution on the basis of inter-personal comparisons. There can be few more intensely political determinations and few for which the judicial process is less suited.

The main tradition takes a pro-consumer policy as the base rule and requires exceptions in particular cases to be made by the legislature, as in the labor laws, the farm program, and the tariff laws. ${ }^{181}$ The Brandeis approach, which seems either to be without a base value or to permit the free creation of exceptions to the base, is fundamentally no different than if a court decided to allow farmers to cartelize because it admired the virtues of agrarian life or undertook to impose a duty upon certain imported goods in order to protect particular producers whose case it found "appealing." The making of exceptions in favor of particular producers, however, is a task for the elected, representative, and explicitly political organs of government. The Brandeis tradition thus involves a serious usurpation of a legislative function by the judicial arm.

181. Even if it be granted that the courts initially participated in choosing the policy of the law in this area, it remains true that the main tradition has the advantage of permitting the courts to stand by the original direction they gave the statute and to leave to Congress any further determination of basic goals. The participation of the courts in selting the initial policy of the statute may not have been wholly or unduly legislative Congress had been concerned with the preservation of competition in passing the Sherman Act. The courts took that concern, and the necessary further values and criteria it implied, and created the present structure of the law. Perhaps the courts of the main tradition ignored other values that were mentioned in the legislative history, but the argument in the text, at pages 834 supra and 840-47 infra, indicates that that was perhags the only course open to them which could make the law both sensible and sufficiently certain. 


\section{The Need for Standards}

By serving a single value the Peckham-Taft-White rule of reason permits the prediction of results and the decision of cases by estimating the position of each fact complex along a single spectrum. Basic ideas of economics calibrate the spectrum for producers who must estimate the risks of behavior and for courts who must decide cases.

This virtue, too, is lacking in a rule of reason which requires the court to decide from case to case whether the spreading of business or some "appealing" purpose, such as a particular benefit to specific producers, is or is not to justify a tax upon consumers or upon other producers. The method of choosing between specific producers and all consumers is not the subject of any social science, or at least not one with propositions and criteria matching those of economics. The choice in each case is between rival and incommensurable values; there is no continuous spectrum between them.

Courts can deal with uncertainty created by the absence of meaningful standards in several ways. One is to refuse to deal with the topic. A second is to declare the statute which contains inadequate standards unconstitutional. A third is to supply by interpretation the certainty that the statute lacks. The first method is rarely open with respect to a statute. The second would have been a possibility with the Sherman Act, but the courts of the main tradition took the third route. They created a case law which used price theory, albeit a somewhat primitive brand, to give the law the structure and criteria it needed. The Brandeis approach, however, lacks the requisite structure and criteria and would put the Sherman Act back in its original state of uncertainty.

The point made here, is not that the explicit adoption of the Brandeis rule of reason would necessarily render section 1 of the Sherman Act unconstitutional, though that would seem a possibility, but that it would create a kind of uncertainty that courts have usually refused to tolerate for extended periods. The argument is best illustrated, however, by cases in which the Supreme Court has dealt with statutes embodying essentially Brandeisian standards (or nonstandards) in the constitutional context of the void-for-vagueness doctrine. The relevant cases are Nash v. United States, ${ }^{182}$ International Harvester Co. v. Kentucky, ${ }^{183}$ United States v. Cohen Grocery Co., ${ }^{184}$ Cline v. Frink Dairy Co., ${ }^{185}$ Trenton Potteries, and United States v. National Dairy Products Corp. ${ }^{186}$ These cases discuss the problem of standards primarily from the viewpoint of the citizen who must obey a criminal law and who is constitutionally entitled to fair warning. Though that seems to be a valid consideration in itself, other cases, notably the reapportionment decisions, suggest that the problem of standards also relates to the ability of courts to

182. 229 U.S. 373 (1913).

183. 234 U.S. 216 (1914).

184. 255 U.S. 81 (1921).

185. 274 U.S. 445 (1927).

186. 372 U.S. 29 (1963). 
function in a judicial fashion. This may suggest that the need for standards is closely linked to the question of which organ of government shall make essentially political choices. ${ }^{187}$

The Nash case involved a challenge to the Sherman Act for unconstitutional vagueness allegedly created by the reading given the law in the Standard Oil and American Tobacco cases. According to Justice Holmes' opinion for the Court, defendants' challenge was not that there were no standards but only that "the statute contains in its definition an element of degree as to which estimates may differ, with the result that a man might find himself in prison because his honest judgment did not anticipate that of a jury of less competent men." Holmes' answer was:

But apart from the common law as to restraint of trade thus taken up by the statute [as shown by Standard Oil and American Tobacco] the law is full of instances where a man's fate depends on his estimating rightly, that is, as the jury subsequently estimates it, some matter of degree. If his judgment is wrong, not only may he incur a fine or short imprisonment, as here; he may incur the penalty of death. "An act causing death may be murder, manslaughter, or misadventure according to the degree of danger attending it" by common experience in the circunstances known to the actor. ${ }^{188}$

Holmes' remark about the statute taking up the common law is likely to be misleading unless read in the light of his remark in the preceding paragraph of the opinion that Standard Oil and American Tobacco "established that only such contracts and combinations are within the act as, by reason of intent or the inherent nature of the contemplated acts, prejudice the public interests by unduly restricting competition or unduly obstructing the course of trade."189 This is recognition that "restraint of trade" was to be interpreted in those economic terms which Holmes in Northern Securities had contended were largely lacking in the common law and hence in the statute. ${ }^{100}$

The constitutional difference that price theory makes may be seen by comparing Nash with International Harvester, Colscn, and Cline. The statutes strack down in those cases all contained a kind of vagueness very similar to that inherent in the Brandeis version of the rule of reason.

187. ... [W] [hen the Court finds a statute unduly vague, it withholds adjudication of the substantive issue in order to set in motion the process of legislative decision. It does not hold that the legislature may not do whatever it is that is complained of but, rather, asks that the legislature do it, if it is to be done at all.

Bickri, The Least Dangerous Branch 152 (1962).

188. 229 U.S. 373, 377.

189. Id. at 376 .

190. It is, therefore, somewhat misleading to say, as Justice Frankfurter later did, that in Nash, "The vagueness of the Sherman Act was saved by imparting to it the gloss of history." Federal Trade Commission v. Motion Picture Advertising Service Co., 344 U.S. 392, 405 (1953) (dissenting opinion). The vagueness was saved initially in TronsMissouri by imparting to the Act the gloss of economics that Chief Justice White later wrote into the history of the common law. 
The International Harvester opinion, also written by Holmes, came in 1914, just a year after Nash. The Court there held invalid under the 14th Amendment's due process clause the antitrust laws of Kentucky under which defendant had been convicted, essentially, for having agreed to sell and for having sold harvesters at a price in excess of their "real value." The state courts had held that "real value" was "market value under fair competition, and under normal market conditions."101 The result, Holmes pointed out, was to require the defendant combination to guess what the market price would have been if the combination had not been formed and nothing else violently affecting values had occurred. He found the problem beyond human ingentity. "The reason is not the general uncertainties of a jury trial but that the ele ments necessary to determine the imaginary ideal are uncertain both in nature and degree of effect to the acutest commercial mind."102 The decision was consistent with Nash's upholding of the Sherman Act which, Holmes said, went "no further than to recognize that, as with negligence, between the two extremes of the obviously illegal and the plainly lawful there is a gradual approach and that the complexity of life makes it impossible to draw a line in advance without an artificial simplification that would be unjust. The conditions are as permanent as anything human, and a great body of precedents on the civil side coupled with familiar practice make it comparatively easy for common sense to keep to what is safe."193

The conditions Holmes called "as permanent as anything human" seem to be the principles of economics, and the contrast he draws is one between a law that employs those principles and common business sense to mark the degrees between competition and monopoly and a law that uses a "real value" test for which, like a reasonable-price test, there are no standards. The Kentucky statute held invalid thus employed a test similar to White's 1897 reasonable price test and to Brandeis' open class of appealing objectives.

The 1921 Cohen decision made even clearer the contrast in constitutional validity between the economic criteria of the main tradition and the vague subjective criteria of the Brandeis tradition. That case struck down under the Fifth and Sixth Amendments section 4 of the Lever Act, a federal criminal statute, which provided: "That it is hereby made unlawful for any person willfully ... to make any unjust or unreasonable rate or change in handling or dealing in or with any necessaries; to conspire, combine, agree, or arrange with any other person ... (e) to exact excessive prices for any necessaries ..."

Chief Justice White, who had given the rule of reason its final phrasing in the 1911 cases, wrote the opinion for the Court striking down this provision for reasons that are applicable equally to the Brandeis approach and to his own position in Trans-Missouri:

Observe that the section forbids no specific or definite act. It confines the subject-matter of the investigation which it authorizes to no element

191. 234 U.S. $216,221$.

192. Id. at 223.

193. Ibid. 
essentially inhering in the transaction as to which it provides. It leaves open, therefore, the widest conceivable inquiry, the scope of which no one can foreshadow or adequately guard against. In fact, we see no reason to doubt the soundness of the observation of the court below, in its opinion, to the effect that, to attempt to enforce the section would be the exact equivalent of an effort to carry out a statute which in terms merely penalized and punished all acts detrimental to the public interest when unjust and unreasonable in the estimation of the court and jury. ${ }^{10-1}$

'Brandeis' approach to the Sherman Act, with its direction to the judge to decide whether or not the purpose or effect of a restraint is appealing, precisely corresponds to the description of the invalid statute in the passage above as penalizing "all acts detrimental to the public interest when unjust and unreasonable in the estimation of the court and jury." Brandeis, unfortunately, did not reach the constitutional issue in Colien, concurring in the result by construing the provision of the Lever Act under review not to cover the case before the Court.

Two 1927 decisions, Cline and Trenton Potteries, further illustrate the problem. The Cline opinion, written by Chief Justice Taft, held the Colorado Anti-Trust Act unconstitutionally vague because it made the lawfulness of certain conspiracies and combinations turn upon a determination of "reasonable profit." ${ }^{\prime 95}$ Trenton Potteries, which preceded Cline, similarly made the constitutional value of price theory clear. In addition to disapproving of Brandeis' dictum in Chicago Board of Trade, Justice Stone attempted to state limitations on the criteria or values subsumed under the rule of reason. Noting that the Standard Oil and American Tobacco decisions held that only unreasonable restraints were prohibited by the Sherman Act, he said,

194. 255 U.S. 81,89 (1921).

- 195. The fatal uncertainty was created by two provisos to the statute. According to Taft's reading,

These provisos make the line between lawiulness and criminality to depend upon, first what commodities need to be handled according to the trust methods condemned in the first part of the Act to enable those engaged in dealing in them to secure a reasonable profit therefrom; second to determine what generally would be a reasonable profit for such a business; and third, what would be a reasonable profit for the defendant under the circumstances of his particular business.

274 U.S. 445, 456-57.

Taft quoted at length from his own opinion in Addyston Pipe \& Steel concerning the impropriety of a reasonable price standard, indicating that he saw not only policy but constitutional objections to a law which required courts to say "in respect to contracts which have no other purpose and no other consideration on either side than the mutual restraint of the parties, how much restraint of competition is in the public interest, and how much is not." This, of course, is precisely what Brandeis' view in Chicago Board of Trode required. Brandeis, however, voted with the Court in Cline.

In the Clitre opinion Taft sometimes did attribute the Sherman Act's sufficient definiteness to the fact that it incorporated the common law precedent, but it must be remembered that Taft in Addyston Pipe \& Steel had forced a policy orientation on recalcitrant common law cases in order to achieve a result essentially indistinguishable from that Pechisam had achieved by disregarding the common law and that White had arrived at by discerning a supposed underlying body of "practical conceptions" in the common law. 
it does not follow that agreements to fix or maintain prices are reasonable restraints and therefore permitted by the statute, merely because the prices themselves are reasonable. Reasonableness is not a concept of definite and unchanging content. Its meaning necessarily varies in the different fields of the law, because it is used as a convenient summary of the dominant considerations which control in the application of legal doctrines. Our view of what is a reasonable restraint of commerce is controlled by the recognized purpose of the Sherman Law itself. Whether this type of restraint is reasonable or not must be judged in part at least, in the light of its effect on competition ...198

The question left open by this passage is what other considerations are allowed by the phrase "in part at least" in the last sentence. We have seen the need for a criterion to balance that of promoting competition. Light is thrown on the constitutional specifications of the necessary counterweight by the reasons Stone gave for rejecting the reasonable price approach. $\mathrm{He}$ rejected it, he said, both because it would place too great a burden of administration and enforcement on the government, and because

in the absence of express legislation requiring it, we should hesitate to adopt a construction making the difference between legal and illegal conduct in the field of business relations depend upon so uncertain a test as whether prices are reasonable - a determination which can be satisfactorily made only after a complete survey of our economic organization and a choice between rival philosophies. Compare U.S. v. Cohen Grocery Co., 255 U.S. 81 ; International Harvester Co. v. Kentıcky, 234 U.S. 216; Nash v. United States, supra. ${ }^{107}$

Two of the citations were, of course, to cases in which the Court had been unwilling to adopt so uncertain a test even in the presence of express legislation requiring it. It would seem, moreover, that Stone's objection to the reasonable price test requires that any other value or criterion entering into the test of reasonableness must be commensurable with that of "effect on competition." Otherwise a court could not weigh the two without becoming involved in "a choice between rival philosophies." Clearly the Brandeis rule of reason which Stone had emphatically rejected involves the attempt to compare incommensurables - a choice between rival philosophies - because it involves a choice between producers and consumers. Though Stone did not draw the conclusion, only by making the policy of the law the creation of wealth can the essential commensurable concept - efficiency - be found to balance against "effect on competition." The predictability thus introduced into the Sherman Act by the Peckham-Taft-White tradition constitutes the difference in result between Nash and Trenton Potteries, on the one hand, and, on the other, International Harvester, Cohen, and Cline.

It has been suggested that the void-for-vagueness doctrine has usually been employed by the Supreme Court to create an added zone of protection around

196. 273 U.S. 392,397 (1927).

197. Id. at 398 . 
certain Bill of Rights freedoms. ${ }^{188}$ International Harzester and Colven are, under this view, reduced in large part to the status of historical curiosities left over from "an era when economic laissez faire was for the Court the sanctum sanctorum that free speech has become today."103 Since economic freedom is not noticeably a sanctum sanctorum for the present Court, this theory may be read too broadly to mean that uncertainty in an antitrust statute, even a criminal antitrust statute such as the Sherman Act, would not today cause great concern, and, therefore, that Brandeis' rule of reason might now be acceptable. The Court's 1963 decision in Unitcd States z'. National Dairy Products Corp., ${ }^{200}$ however, indicates that this is not the case, and that the Court continues to refuse to tolerate lack of standards, even in an economic regulation.

The district court in National Dairy had dismissed an indictment laid under section 3 of the Robinson-Patman Act, which makes it a crime to sell goods at "unreasonably low prices for the purpose of destroying competition or eliminating a competitor," on the ground that the statute was unconstitutionally vague and indefinite. A majority of the Supreme Court reversed, but read the statute to prohibit sales below cost made with a predatory intent..01 This was the familiar judicial device - an alternative to a declaration of unconstitutional vagueness - of gaining the necessary statutory certainty through interpretation. ${ }^{202}$

The National Dairy opinion distinguished Colen because neither the statute nor the indictment there specified a definite act that was prohibited, and,

Moreover, the standard held too vague in Cohen was without a meaningful referent in business practice or usage .... In view of the business practices against which section 3 was unmistakably directed and the specificity of the violations charged in the indictment here, both absent in Cohen, the proferred analogy to that case must be rejected..$^{203}$

198. Amsterdam, The Void-for-Vagucness Doctrine in the Suprene Court, 109 U. PA. L. REv. 67, 75 (1960).

199. Id. at 77 .

200. 372 U.S. 29 (1963).

201. To the objection that the standard of "below cost" was itself unconstitutionally vague, the Court replied that it did not have to decide this point on appeal from the granting of a pretrial motion because it might develop at trial that National Dairy had sold below any type of cost the words might indicate.

202. The majority opinion analogized its tactic here to that employed in Screws v. United States, 325 U.S. 91 (1945), which read a requirement of specific intent into a federal statute making it a crime willfully to subject, under color of state law, any inhabitant of a state "to the deprivation of any rights, privileges, or immunities secured or protected by the Constitution or laws of the United States" in order to save the law from fatal vagueness.

203. 372 U.S. at 36. Justice Clark's opinion for the majority, while it does not bear out the idea that International Harvester, Cohen, and Cline can be relegated to an historical ashpile, does suggest that the vagueness problems may be approzched differently in cases involving economic regulation and those involving First Amendment problems. In the latter, he said, the Court is concerned with the vagueness of the statute "on its face" because such vagueness may in itself deter constitutionally protected and socially desirable conduct ..... 
The constitutional importance of economic theory is again shown by the suggestion that a "meaningful referrent in business practice or usage" existed for section 3 of the Robinson-Patman Act but not for the Lever Act. The distinction seems to rest on the assumption that there is an economic theory which distinguishes predatory price cutting from other kinds of price cutting but none which distinguishes unreasonable from reasonable rates.

The Court's method of narrowing section 3 of the Robinson-Patman Act as applied in the particular case may not be a wholly satisfactory solution to the vagueness of that statute, but it demonstrates the continuance of real concern over the problem of vagueness even when the freedoms at stake are economic. This suggests that it is not entirely the quality of the freedom that impels the Court but also the problem of vagueness itself. The point is emphasized by the fact that Justice Black, dissenting in an opinion in which Justices Stewart and Goldberg joined, - a group that cannot be described as committed to economic laissez faire as a constitutional value - contended that section 3 of the Robinson-Patman Act was flatly unconstitutional under the rule established in Cohen.

That the judicial need for standards goes deeper even than the constitutional requirement of fair warning is suggested by the historical progression of the Supreme Court's treatment of the problem of state legislative reapportionment. A large element in the resistance of some members of the Court to its entry into that field was the inherent lack of

accepted legal standards or criteria or even reliable analogies to draw upon for making judicial judgments. To charge courts with the task of accommodating the incommensurable factors of policy ... is to attribute, however flatteringly, omnicompetence to judges. ${ }^{204}$

Notice was taken of "the caution not to undertake decision where standards meet for judicial judgment are lacking." 205

It may be significant that when the Court did undertake the reapportionment of state legislatures it moved speedily to the only firm criterion available - "one person, one vote"206 — which had the overwhelming virttic, despite considerable defects as history or as political or constitutional theory, ${ }^{207}$ of being at least a standard.

No such factor is present here where the statute is directed only at conduct designcd to destroy competition, activity which is neither constitutionally protected nor socially desirable.

Thus, the Court would judge a statute impinging upon First Amendment frecloms for the definiteness or lack of it that it displayed on its face but would look at section 3 of the Robinson-Patman Act not only in terms of the statute "on its face" but also in the light of the conduct to which it is applied.

Put in terms of the degree of danger of deterring socially desirable conduct, this distinction between statutes aimed at unwanted speech and at excessive price competition may be somewhat shaky, but it does suggest a different approach to the void-for-vagueness doctrine when constitutional values are close by.

204. Frankfurter, dissenting, in Baker v. Carr, 369 U.S. 186, 268 (1962).

205. Id. at 289.

206. Gray v. Sanders, 372 U.S. 368,381 (1963). 
The Brandeis rule of reason lacks "standards meet for judicial judgment" and it is, therefore, to be expected that the explicit, full-scale adoption of that approach would create uncertainties which the courts would not long tolerate. The progression of the legislative reapportionment cases suggests that a conscious adoption by the courts of the Brandeis rule of reason would shortly be followed by the evolution of arbitrary rules concerning the purposes for whih cartelization is allowable.

Peckham, Taft, and White, when they first dealt with the vague language of the Sherman Act, faced a problem not unlike that posed for the Court by the statutes involved in International Harvester, Cohen, Cline, National Dairy, and by the topic of legislative reapportionment. Their solution was to employ the standards provided by the basic ideas of price theory to give the law relating to agreed eliminations of competition the standards required. Standards, though of varying degrees of merit, were similarly found in National Dairy and in the field of legislative reapportionment. No standards were at hand to be incorporated by interpretation in International Harvester, Colren and Cline, and so the statutes there fell.

The arguments made above concerning the unreality of the distinctions of the Brandeis approach, the relative effectiveness of the Sherman Act in inplementing the different values of the law's two traditions, and the respective roles of legislatures and courts in choosing values and making interpersonal comparisons, indicate that the criteria of the main tradition which give certainty to the Sherman Act are vastly superior to those that could be created by judicial interpretation within the Brandeis tradition. 203

If it is true that the Brandeis rule of reason as a whole represents an improper approach for the courts, it should not require further agument that those elements of it which intermittently appear in decisions and enforcement policy are illegitimate and should be eliminated. In considering the correct treatment of the various forms of price fixing, market division, and analogous eliminations of competition by agreement with which the law must cope, therefore, the second part of this paper will confine itself to the policy approach of the law's main tradition.

207. See Neal, Baker v. Carr: Politics in Search of Law, 1962 SuP. CT. REv. 252.

208. An additional element of the main tradition's superiority, related to the fair warning concept, is that the law may be corrected with less likelihood of unfairness to persons who have relied upon prior decisions. A court attempting to apply the cconomic criteria of the main tradition may, of course, mistakenly approve a disguised cartel. Nicvertheless, persons who subsequently make similar agreements may be presumed to bnow the actual purpose and effect of their arrangements. Their reliance, therefore, can only be upon the continued incorrect application of known principles. The Brandeis rule of reason scems to have greater stress upon stare decisis, and so greater rigidity, built into its doctrines. Producers would often be invited to rely upon decisions that certain kinds of climination of competition are desirable in and of themselves. A later court might find the attractiveness of such cartelization less obvious, but it would surely feel less free to correct the lav because it could not truthfully say that persons who had relied upon the prior case should have known it was incorrectly decided. 